\title{
Competition Issues in India's Online Economy
}

No. 194

03-Apr-2017

Smriti Parsheera, Ajay Shah and Avirup Bose

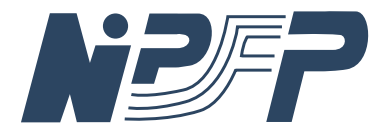

National Institute of Public Finance and Policy New Delhi 


\title{
Competition issues in India's online economy
}

\author{
Smriti Parsheera* Ajay Shah ${ }^{\dagger}$ Avirup Bose ${ }^{\frac{6}{3}}$
}

March 31, 2017

\begin{abstract}
The world of high technology companies is seen as a dynamic area with a rapid pace of creative destruction. There is, however, a class of industries where there are strong network effects, where the market tends to collapse into a narrow set of players. After one burst of innovation where a new online business is born, there is the possibility of entrenched market power with the extraction of consumer surplus.

Many firms, global and Indian, have resorted to the strategy of making large losses by subsidising users, as a way to obtain those network effects. This has created a new class of concerns about predatory pricing, with unprecedented negative profit margins on a sustained basis, being supported by equity capital infusions. In the short run, discounts are popular, but recoupment is inevitable and market power will adversely affect consumers in the future.

We argue that the existing competition law regime in India needs to be fine tuned, for technology-enabled markets with significant network effects, to address the possibility of new kinds of abusive conduct. We offer a series of tangible proposals through which the Competition Commission of India can better handle these emerging situations. We also look into the role and responsibilities of the investors who back these online businesses and the impact of their conduct on competition in the underlying markets.
\end{abstract}

\footnotetext{
${ }^{*}$ Consultant, National Institute of Public Finance and Policy.

${ }^{\dagger}$ Professor, National Institute of Public Finance and Policy.

$¥$ Assistant Professor of competition law and policy, Jindal Global Law School.

${ }^{\S}$ We thank Pratik Dutta, Samir Gandhi, Kaushik Krishnan, Sanjay Pandey, Ila Patnaik, Indrajeet Sircar, Somasekhar Sundareshan and other participants at NIPFP's Law, Economics and Policy Conference, 2016 for their comments. All errors are our own.
} 
Working paper No. 194

\section{Introduction}

Innovation is the foundation of economic progress. While we normally revere technology companies for their disruptive innovations and the efficiencies that they create, we must recognise that some technology-driven businesses are susceptible to the acquisition and abuse of market power. The Indian competition regime is an evolving one, and has only recently started facing some of these concerns. This paper brings new evidence and arguments to the table, on these questions.

Internet-based businesses, along with several other high-technology sectors, form part of the 'new economy', characterised by high rates of innovation; low marginal cost; increasing returns of scale; and, in many cases, network effects. Direct 'network effects' arise where a user's benefit from a product or service increases with the number of other users on that network. The benefit of being on Facebook or WhatsApp, for instance, corresponds with the number of friends and family who use that service. Contrast this with the benefit of having an email address, where the benefits are not limited to closed proprietary networks. This became possible due to the early adoption of interoperability standards in email protocols.

Network effects are particularly important in two-sided markets where users on each side of the market derive a positive effect from the expansion of users on the other side. Commuters who use taxi aggregation platforms like Ola and Uber will logically be attracted to a service that has a large number of drivers on its network, which yields a lower waiting time. The same is true for the drivers working with these platforms. Similarly, in case of payments wallets, in the absence of interoperability regulation, merchants and customers will both prefer a service that has the most addressable users.

With the use of modern technology, the cost of running the marketplace itself has dropped to near zero levels. As an example, the online classifieds site Craigslist reports that it has about 40 employees who manage a network that sees over 80 million classified ads per month. The marginal cost of a transaction has gone to near-zero levels. This gives a unique class of problems where technological innovation that yields cost reductions cannot be a mechanism to take on an incumbent.

How can market power be established, in this new world? One mechanism through which one player can obtain a competitive advantage is to attract users through technological innovation, and thus get a network effect started. This is an attractive strategy for firms which have deep human capital. An- 
other mechanism is by using financial capital to pay subsidies that entice users. This is an attractive strategy for firms which have superior access to financial capital. Many online businesses have resorted to practices like deep discounting, cash-back offers and other schemes designed to attract new users and establish the network effect. Sometimes, heavy losses have been sustained for years on end.

As an example, the global taxi company 'Uber' made worldwide losses in the first half of 2016 of US $\$ 1.27$ billion (approximately Rs.86.5 billion). ${ }^{1}$ Uber's behaviour impacts upon the Indian economy as it has applied the strategy of using financial capital as a competitive lever in India also. On a similar note, the Indian taxi company 'Ola' reported a net loss of Rs.7.96 billion in March, 2015. The company's financial records for the periods after that are not yet available although it is reasonable to expect that the losses will be significantly higher due to the higher driver incentives. In the last two years, it is estimated that the two taxi companies, Uber and Ola, burnt cash adding up to about Rs. 130 billion in India. Such behaviour is found in other industries also. In the field of payments, where regulations have blocked interoperability and thus created the opportunity to kick off a network effect, the firm One97 Communications, which owns 'PayTM', reported a loss of Rs.15.49 billion in March, 2016. ${ }^{2}$

The scale of these discounting practices, and the sustained periods for which they are continued, has created new barriers to competition. It is difficult to rationalise these sustained losses as being an introductory offer by a new player. Rather, these practices appear to be a systematic competitive strategy. Capital has become a competitive weapon. This gives rise to concerns that the market may eventually tip in favour of the player that may not necessarily have the most innovative product or service, but one that succeeds in obtaining more capital and enticing more users in the early days, using subsidies. While seeming beneficial for consumers in the short run, such practices raise concerns about competition on account of the creation of market power, and elevated prices for consumers in the following years when losses are recouped.

The foreign direct investment (FDI) guidelines issued by the government in March, 2016 turned the spotlight on pricing practices of e-commerce firms. It clarified that the automatic route of foreign investment would be available only to those e-commerce marketplaces that refrained from influencing sale

\footnotetext{
${ }^{1}$ See Newcomer (2016).

${ }^{2}$ See Mishra (2016).
} 
prices and helped maintain a level playing field. ${ }^{3}$

These issues have also come to the attention of the Competition Commission of India (CCI) in a few recent cases. In April 2015, the CCI passed a prima facie order recommending a detailed investigation into the allegation that, armed with substantial funding received from various investors, Ola had indulged in abusive market practices to garner greater market power in the city of Bengaluru. ${ }^{4}$ More recently, the Competition Appellate Tribunal (COMPAT) directed the Director General of the CCI to initiate a similar investigation to assess Uber's dominance in the market for radio taxi services in the National Capital Region (NCR) of Delhi after the CCI had refused such an investigation. ${ }^{5}$ Uber has now challenged this decision before the Supreme Court, citing a "jurisdictional flaw" in the Tribunal's ability to order such an investigation. Alongside these developments, CCI is also reported to have set up an in-house panel to understand the cash-back incentives being offered by various online companies from the perspective of predatory pricing provisions under the Competition Act, 2002 (Act). ${ }^{6}$

This paper explores the recent developments in India in this area, in the light of foundations of economics and competition law. It argues that there are grounds for concern about the harm to competitive dynamics from these new business strategies. At the same time, it is important to avoid intrusive interventions that bring the State into excessive involvement in the world of business. Our proposals are as follows.

First, there is a need to take into account the distinct economic features of certain high-technology businesses when looking into allegations of anticompetitive conduct by them. Practices like deep discounting and cash back offers may be aimed at building sufficient scale in today's market to ensure that the business is able to fully capture tomorrow's market, to the exclusion of other competitors. A robust economic analysis of the impact of increasing

\footnotetext{
${ }^{3}$ Press Note 3 (2016 Series) (2016) issued by the DIPP on 29 March, 2016 allowed 100 percent FDI in the marketplace model of e-commerce under the automatic route, subject to specified conditions. The "marketplace based model" is defined to any information technology platform created on an electronic network, that allows an e-commerce firm to act as a facilitator between buyers and sellers.

${ }^{4}$ Fast Track Call Cab Private Limited v. ANI Technologies Pvt. Ltd., Case No. 6 of 2015, CCI order dated 24 April, 2015. A separate case filed by Meru Travel Solutions against Ola (Case No. 74 of 2015) was subsequently clubbed with this case owing to the similar facts and allegations.

${ }^{5}$ Meru Travels Solutions Private Limited v. Competition Commission of India, Appeal No.31/2016, COMPAT order dated 7 December, 2016.

${ }^{6}$ Arora (2016) reports that this move follows several complaints received by the Commission on such discounting and cash-back offers by online businesses.
} 
returns to scale, and network effects, is required for understanding the present and future impact of these practices on competition and consumer interests. A novel dimension, which is addressed in the paper, concerns collaboration between the investors in the multiple firms that they invest in.

Second, we examine the question about gains to consumers from discounting. We suggest that the gains in the short term need to be seen in a larger context. The recoupment test examines the extent to which market power can be achieved in the future, after which prices can be raised. If the CCI were to adopt this test in investigations relating to predatory pricing by online firms it would see that in certain areas, there are network effects, and once a small cartel of firms has acquired market power, it would be difficult for entrants to compete with them in the future. In that future scenario, it would be possible for incumbents to raise prices, and recoup earlier losses.

Third, in appropriate cases, the CCI could rely on the essential facilities doctrine to mandate interoperability between a dominant player that is found to be indulging in the abuse of its position and other operators in the market. For instance, imposing interoperability requirements on a dominant payments network can help extend the network effects of digital payments to the economy as a whole, rather than being limited to a closed network. The imposition of any such requirements will, however, need to be balanced against factors such as the payment of fair and reasonable access fees, the complexity of institutional arrangements required to monitor such arrangements and assessment of the impact on future innovation. More generally, open standards are an important element of interoperability, and various arms of the regulatory State need to push in favour of competitive markets through interoperable open standards.

Fourth, given the fast-changing nature of online businesses, there are concerns about the elapsed time between a full-fledged investigation and the determination of a violation. We suggest a two-pronged approach to address this issue. On one hand, the CCI needs to work towards adopting stricter time frames for the disposal of cases, particularly those relating to new economy firms. On the other, we propose a voluntary settlement process that will allow a business that is under investigation to voluntarily alter its market behaviour, with the concurrence of the authority but without the need for a conclusive finding of violation by the CCI.

These issues were not faced in thinking about Indian competition policy as recently as five years ago. They are, however, likely to become increasingly important in the future. We argue that this calls for fresh think about the legal framework also. There is a case for competition authorities to look into 
the unilateral abusive conduct of a firm, which, although not dominant at the given point of time, is engaging in anti-competitive practices that create a strong and imminent possibility of its dominance. We highlight some pros and cons of this approach and leave this question open for further research.

The remainder of this paper is organised as follows: Section 2 lays down the key economic characteristics of new economy firms, particularly with a focus on online businesses; Section 3 presents an overview of the competition concerns that can arise on account of the conduct of venture capital (VC) and private equity (PE) funds that invest in online businesses; this is followed by a discussion in Section 4 on CCI's current jurisprudence in this area and on network industries, generally; and finally in Section 5 we present our proposals on the way forward.

\section{The nature of competition in online busi- nesses}

\subsection{Characteristic features of the sector}

The term 'new economy' is often used to describe sectors of the economy that produce or intensely use new technologies, with an increasing dependence on computers, telecommunications and the Internet (OECD, 2004). Online businesses, which encompass a range of applications, services and content available on the Internet, form an important part of this sector. Certain key features set these businesses apart from the traditional or 'old' economy. ${ }^{7}$ These are:

1. High rates of innovation and rapid technological changes.

2. Increasing returns of scale - cost of production reduces with scale.

3. Network effects - demand-side economies of scale.

Rapid innovation and technological changes in the new economy often cause the firms in question, and the markets in which they operate, to remain in a

\footnotetext{
${ }^{7}$ Posner (2000) observes that the general characteristics of traditional industries include limited economies of scale at both the plant and firm level; stable market conditions; heavy capital investments; modest rates of innovation; and slow and infrequent entry and exit of firms. See Graham (2004), Teece and Coleman (2003), Evans and Schmalensee (2002), OFT (2002) and Posner (2000) for a discussion about the general characteristics of industries in the new economy.
} 
constant state of flux. This helps contain market power. The growth of 'over the top' Voice over Internet Protocol (VoIP) and video calling services like Skype has, for instance, revolutionalised the manner and the cost at which people connect with one another. In doing so it has created competitive pressures on traditional telephone networks. Similarly, there have been radical shifts in gaming technologies, from the Game Boy style handheld devices to Internet-enabled consoles and now virtual reality headsets. In each case, do these services/ technologies constitute a separate market or has the underlying market expanded to include them within its scope? Graham (2004) describes this episodic "alternation of the markets under consideration either through the creation of new markets or transformation of old ones" as a basic feature of the new economy. ${ }^{8}$

Continuous innovation and low entry and exit barriers, including in the form of regulatory requirements, have enabled the rapid growth of Internet-based businesses. However, it would be premature to suggest that market power is absent in these areas. In fact, some of these markets also exhibit two other key features - increasing returns and network effects - that lead to the creation of a 'winner-takes-all' or at least a 'winner-takes-most' phenomenon. ${ }^{9}$ This calls for a need to take a closer look at issues of creation and consequent abuse of monopolies in these markets, which is the focus of this paper.

The phenomenon of increasing returns implies that as the business expands in scale, costs keep falling, making it that much easier for the business to go much further. Evans and Schmalensee (2002) explain that this occurs because these industries typically face higher fixed cost (investments in research and development or creation of a physical or virtual network) and relatively lower marginal costs. This makes it cheaper to create additional units of output. For instance, once a software has been created, the cost of replicating it is almost negligible. The consumption of each additional unit only brings down the costs.

\footnotetext{
${ }^{8}$ This is also linked to the heavy reliance by businesses in this sector on the intellectual property rights (IPR) regime to safeguard themselves against future competitive threats (Graham, 2004). The United States, for instance, has a history of granting business method patents to protect the way in which companies run their business, which has been used by many online businesses to shield themselves from competitive challenges. Examples include the patenting of Amazon's one-click shopping technology and Netflix's subscription rental service model. In contrast, the Indian Patents Act, 1970 does not allow the grant of patent protection to business methods or computer algorithms, as these are not regarded as 'inventions' under Indian law.

${ }^{9}$ See Economides (2004) for a comprehensive discussion on the special features of markets with network effects.
} 
The next feature, and one that is particularly relevant for the present analysis, is that of demand-side economies of scale - network effects. Network effects occur when the benefit that a consumer derives from a product or service increases with an increase in the number of other users. 'Metcalfe's Law' uses this logic to propose that the value of a communication network is proportional to the square of the number of participants. While the figures may be debated, ${ }^{10}$ it is easy to understand how this logic applies to social network like Facebook or a messaging service like WhatsApp - they become increasingly more valuable as more people start using them.

Some other businesses in this segment yield 'indirect network effects', where the network's value increases not with the number of similar uses but with an increase in complementary users or services. Indirect network effects acquire a particularly interesting dimension in two-sided markets where users on each side derive a benefit from the addition of new users on the other side. Examples include platforms like e-commerce marketplaces (Amazon and Flipkart) that connect retailers with end customers; online classifieds (Olx and Quikr) that bring together buyers and sellers; and online taxi aggregation services (Uber and Ola), which connect commuters and drivers. In each case, the increase in users on one side of the market makes the platform that much more attractive for users on the other side - more commuters want to use a taxi service that has more drivers on its platform; and more sellers want to participate in a market that attracts more buyers.

Two-sided markets also bring with them the possibility of charging prices on both sides of the market. This allows for complex pricing strategies that can be used to leverage a firm's strategic position on one side of the network (Economides, 2004). For instance, a website may earn its revenues by charging users a subscription fee; or it may provide free content to users, generating income through advertising revenues. The battle between Google and Facebook and numerous other "free" online services is therefore about capturing the maximum 'eyeballs', which determines winners and losers in the market for digital ad spendings (Ovide, 2016). Technology has also made it easier for firms to obtain information about pricing preferences and buying patterns and create different versions of the product to suit different price points (Graham, 2004). One example of this is 'surge pricing' by taxi aggregation services. This raises the possibility of price discrimination schemes which extract consumer surplus.

These characteristics are closely tied in that they both speak to the benefits that can be derived from reaching a certain scale. However, while increasing

\footnotetext{
${ }^{10}$ See Bob Briscoe and Tilly (2015).
} 
returns is a supply side phenomenon - outputs increasing with a scaling up of inputs - network effects arise on the demand side - value increasing with the number of other users (Teece and Coleman, 2003). This combination of supply and demand economies leads to what Shapiro and Varian (1999) refer to as a situation where "growth on the demand side both reduces cost on the supply side and makes the product more attractive to other users accelerating the growth in demand even more." While these factors are not exclusive to online businesses, ${ }^{11}$ the effects that they produce are significantly deepened due to the steep pace at which these businesses are able to build scale. Two other factors contribute to this result.

First, is the concept 'data network effects', which "occur when your product, generally powered by machine learning, becomes smarter as it gets more data from your users" (Turck, 2016). Google's search engine, Facebook's news feed and Zomato's restaurant recommendations are all examples of powerful algorithms that utilise user generated data to make the product smarter and more relevant for the needs of their users. This in turn attracts more users and further entrenches the scale effects (Malik, 2015; Turck, 2016).

Second, is the availability of significant capital resources to support the funding needs of this sector. The lean design of most online businesses ensures that they have modest capital requirements compared to similar businesses in the brick and mortar world. Added to this is the likelihood that the firm that achieves a head start in the race to deliver a useful product will be rewarded with windfall gains as financial investors understand the impact of network effects upon profitability.

For instance, Sequoia's US\$ 8 million investment in WhatsApp in 2011 is reported to have translated into about US\$ 3.5 billion of returns when the latter was acquired by Facebook in February, 2014 (Levy, 2015). While announcing the deal, Sequoia attributed WhatsApp's success to the fact that it had over 450 million active users and had reached that number faster than any other company in history; it maintained a lean organisation structure with extensive reliance on technology; it chose not to collect or use personal information of users; and it relied on word of mouth publicity rather than marketing to create the "viral nature of WhatsApp" (Goetz, 2015). Each of these features, barring the use of personal information, which subsequently came to be reversed under the new ownership, points to one or more of the core features of new economy industries.

\footnotetext{
${ }^{11}$ Evans and Schmalensee (2002) note that some old-economy industries like gas, electricity and railways also witness increasing returns. Similarly, the telecommunications industry displays strong network effects.
} 
Financial investors are openly talking about the quest for business models that contain network effects, and the market power that they confer. Every investor is vying to invest in the next Amazon, Facebook, Uber or Airbnb. In the last decade, India saw PE investments of over US\$27.6 billion in the information technology (IT) and IT-enabled services sector, with a recorded high of US\$ 7.6 billion worth of investments in $2015 .{ }^{12}$ The results of these large capital infusions are illustrated by the fact that all Indian 'Unicorns' a term used for an unlisted company with a valuation of over US\$ 1 billion - belong to the new economy, with most being Internet-based businesses. ${ }^{13}$ The year 2016, however, saw a significant dip in investments with a total of US $\$ 10.34$ billion of funding, of which, US\$ 3.02 billion was in the IT sector. ${ }^{14}$

\subsection{Implications for competition in the sector}

Having laid out the basic economic characteristics of new economy industries in the context of online businesses, we now turn to examine whether these features could give rise to any special anti-competitive concerns.

As noted by Economides (2004), the aim of competition law is to protect markets from restrictions or impediments to competition that will remain uncorrected by natural market forces. This is especially true for "winnertakes-most' markets, which have a "structural tendency to display extreme market share and profit inequality" (Economides, 2004). Firms are therefore willing to incur short-term losses in the hope of becoming the ultimate winner in the long-run. ${ }^{15}$

The extent of losses being incurred by e-commerce firms in India through heavy discounting practices is testimony to the value that these businesses expect to gain from ensuring early control over the market. It is reported that the combined losses of India's top ten e-commerce companies quadrupled in the financial year 2014-15, standing at a total of Rs.51.5 billion. Leading ecommerce marketplaces bore the highest proportion of these losses - Flipkart at Rs.20 billion, Amazon India at Rs.17.2 billion and Snapdeal at Rs.13.28

\footnotetext{
${ }^{12}$ Venture Intelligence, PE Database.

${ }^{13}$ See Bhagya (2006) for details of Indian Unicorns like Flipkart, Ola, Zomato, MuSigma, InMobi, etc.

${ }^{14}$ See VCC (2016).

${ }^{15}$ Rubinfeld (1998) notes that firms in dynamic high-technology markets often find it efficient "to compete jointly for today's and tomorrow's markets", adopting strategies that will help them gain control of the market in the long-run.
} 
billion. ${ }^{16}$

The balance sheets of taxi aggregator Ola, which competes with Uber in India, show a similar trend. In the financial year ending March 2015, Ola's revenue from operations stood at Rs.3.8 billion. In comparison, it had total expenses of Rs.11.2 billion, $82 \%$ of which (Rs.9.2 billion) was on 'fleet operator costs'. This reflects the large scale incentives being given by Ola to taxi operators to build scale in the business. During the same period, approximately Rs.998 million was spent by the company on 'advertising and sales promotion' expenses, which accounts for the incentives and benefits paid to attract cab users to the service. Therefore, in effect, Ola paid about Rs.2.5 as incentives for every one Rupee that it earned.

Despite increasing revenues, the sharp rise in operating expenses has caused the company's losses to increase manifold in the last three financial years. At the end of March 2013, Ola reported net losses of Rs.228 million, which rose to Rs.342 million in March, 2014 and Rs.7.9 billion in March, 2015. Ola's losses in the next two financial years are likely to be significantly higher as the company pursued an even stronger push towards driver subsidies in those periods.

Uber's worldwide losses are much larger. In the seven years of its existence Uber is reported to have lost at least US\$ 4 billion, of which about US\$1.27 billion (approximately Rs.86.5 billion) was in the first half of $2016 .{ }^{17}$ In the last two years, it is estimated that the two taxi companies, Uber and Ola, burnt over Rs.130 billion of cash in India. ${ }^{18}$ This business model of heavy ongoing expenditure on building scale is in fact contrary to one of the key characteristics of new economy industries - that of operating with very low marginal costs.

Let us try to map these market developments against the economic principles that drive many online businesses. Very often, the natural equilibrium of a

\footnotetext{
${ }^{16}$ See Vats (2016). Mazumdar (2016), however, notes that the discount levels have begun to decline in recent months due to pressure from investors to improve the profitability of these businesses. The extent of cash burn that we have seen in e-commerce marketplaces in recent years may therefore be on a decline.

${ }^{17}$ See Newcomer (2016).

${ }^{18}$ Based on the estimate that each taxi aggregator records about 500,000 rides per day, which is lower than the 1 million rides per day reported for Ola and the 5.5 million rides per week for Uber (See Arakali (2016) and Busvine (2016)). It is assumed that an average fare of Rs.200 is earned per ride, on which the aggregator charges a commission of 30 percent (Rs.60). Further, based on Ola's balance sheet for the period ending March, 2015 and subsequent reports of increase in driver incentives, we assume that the incentive expenses will be at least 3 times the company's operational revenues.
} 
network industry is for the market to be dominated by one or a few firms. Therefore, once the first few firms have gained the benefits of network effects, "the addition of new competitors, even under conditions of free entry, is not likely to change the market structure in any significant way" and may even lead to a reduction in the overall surplus (Economides, 2004). ${ }^{19}$

This is also linked to the fact that network industries often involve a 'tipping point' - a point at which a business acquires such a large number of users that it is logical for the market to tip in its favour. Tipping can have a beneficial outcome in situations where two or more firms are competing on the basis of innovation and network effects make it possible for the better firm to emerge as the market leader. In such a case, tipping will maximise the size of the network, hence increasing consumer benefit (Rubinfeld, 1998). However, tipping can also take place for other reasons, sometimes in favour of the player that does not necessarily have the most innovative product or service. ${ }^{20}$ This is sometimes termed as the problem of 'network failure' - a situation where the technology or network that manages to achieve the highest scale on account of network effects is not the best one, leading consumers to suboptimal choices. The popularity of the QWERTY keyboard and the video home system (VHS) recording format over the Betamax format are often cited as examples of the lock-in effects created on account of network failures (Greenhalgh and Rogers, 2010). ${ }^{21}$

Similarly, the market could also tip in favour of a business that uses financial means, such as, its ability to offer deep discounts, offers, schemes and other incentives, to attract users to its platform in order to build scale, although its product may not necessarily be technologically superior. Increasing returns to scale and network effects will then take their course, setting the firm on its the path of dominance. A number of VC-backed online businesses are

\footnotetext{
${ }^{19}$ Economides and Flyer (1998) illustrate this phenomenon with an example of a "pure network good", which has no value in the absence of network externalities. They find that the market equilibria in such a situation exhibit extreme inequality - a firm can charge only a fraction of the price of its next larger firm and makes a very small profit and the entry of new players hardly has any effect on the market.

${ }^{20}$ For instance, Rubinfeld (1998) notes that a "change in the expectations of a substantial number of users about the likely eventual size of the network" may drive them to opt for a particular business.

${ }^{21}$ Liebowitz and Margolis (1994) however argue that these claims are highly conjectural in nature. The authors acknowledge that theoretical literature establishes that within models that incorporate particular abstractions, market failure of the type that causes the wrong network to be chosen is possible. They are, however, of the view that if the concept of network externalities is to have any relevance, it should be supported by real examples of demonstrable market failure.
} 
choosing to opt for this route. For example, payment wallets like PayTM, Mobikwik and Freecharge offer attractive cash-back discounts for almost every transaction carried out on their platform. The goal is to get as many users and merchants on to their networks in the quickest time frame possible. In the absence of interoperability between these services, users would logically gravitate towards the service that connects them to the maximum number of end points.

An early-mover with a reasonably large customer base may therefore be able to restrict the competitiveness of other firms by making sure that rival products are not compatible with its own. ${ }^{22}$ To take an example, Google has been questioned by competition authorities in various jurisdictions for making its advertising platform, Google AdWords, incompatible with competing ad platforms. Google imposed contractual conditions that made it difficult for advertisers using AdWords to simultaneously manage advertising campaigns on competing ad platforms, hence giving rise to concerns of abuse of dominance through exclusionary conduct. ${ }^{23}$ Similar concerns are also seen in the case of digital payment platforms where the absence of interoperability between players will lead to concentrated networks, thus enhancing monopoly powers and hampering the widespread adoption of digital payments. The imposition of mandatory interconnection regulations on all payment providers (banks and non-banks) is one way to adress this issue. ${ }^{24}$ This has also been recommended in the recent Report of the Committee on Digital Payments (Watal, 2016).

Sector-wide interoperability norms are best determined under an ex ante regulatory framework, as seen in case of the interconnection norms imposed by the Telecom Regulatory Authority of India. The CCI could, however, in appropriate cases, use its powers under the Act to mandate interoperability by a dominant player that is found to be indulging in an abuse of its position. For instance, in the Microsoft case, the European Commission found that Microsoft had abused its dominant position in the PC operating system market by refusing to supply interoperability information to its competitors. It was accordingly directed to disclose the complete and accurate interface information that would allow rival vendors to interoperate with the Windows

\footnotetext{
${ }^{22}$ See Farrel and Katz (1998) for further discussions on how product compatibility can affect competition in network industries.

${ }^{23}$ In January, 2013, Google issued a commitment to the Federal Trade Commission (FTC) in the United States, agreeing to remove such restrictions (FTC, 2013).

${ }^{24}$ Shah (2016a) notes that the field of payments is evolving as a distinct industry that will be dominated by technology companies. This requires interconnectivity regulation in order to ensure that banks and other incumbents are not able to hamper new players.
} 
system. ${ }^{25}$ Economides and Lianos (2010), however, point to the complexity of the institutional arrangements required to monitor the proper compliance of this interoperability decision.

The essential facilities doctrine, which was originally adopted in a decision of the Seventh Circuit Court in the United States, creates such a framework for mandating access to an "essential" facility that is required to be accessed by other players in order to compete effectively in the market. ${ }^{26}$ The Court referred to the following elements as being necessary to establish the applicability of the essential facilities doctrine:

1. the monopolist controls access to an essential facility;

2. the essential facility cannot be practically or reasonably duplicated;

3. denial of the use of the facility by the monopolist; and

4. feasibility of providing the facility.

A similar criteria can be considered by the CCI while looking into the appropriateness and feasibility of mandating interconnection by a dominant player that controls any product or service that could be characterised as an essential facility. Khan (2017) notes that although this doctrine "has not yet been applied to the Internet economy, some proposals have started exploring what this might look like". Using the example of Amazon's services in the US market, the author finds that applying the essential facilities in such a context would make sense given the control that it exercises over key infrastructure for e-commerce services.

\subsection{Incentives of firms and investors}

The factors discussed above explain the importance of a first-mover advantage in the technology sector. The valuation of Internet-based businesses and the likelihood of them attracting PE investments is also closely connected with the pace at which they are able to build scale - attracting more users at an early stage will make it that much easier for the business to attract more users, and hence exclude other competitors. Similarly, from the investor's perspective, the profitability of its investment and success of its

\footnotetext{
${ }^{25}$ Case COMP/C-3/37.792 Microsoft, Commission decision dated 24 March, 2004.

${ }^{26}$ MCI Communications Corp. v. ATET, 708 F.2d 1081 (7th Circuit). The US Supreme Court in Verizon Communications Inc v. Law Offices of Curtis V. Trinko LLP, 540 US No. 02-682 [2004] has, however, shown a reluctance towards adopting the essential facilities doctrine.
} 
exit strategy is directly linked to the scalability of the portfolio company. Startups and investors are therefore aligned in their incentives to increase market share in the quickest time frame possible.

Armed with the capital generated by the investors' desire to load the startup up-front and expedite customer acquisition, online startups are engaging in a range of practices to facilitate the tipping of the market in their favour. As noted by Shah (2016b), "money has become the raw material" in the Indian technology landscape, with new businesses focusing on the quickest path to network effects rather than relying on scientific innovation or improved quality as the tools to garner market share. The resulting monopolistic or oligopolistic market structure arising from the entry barriers created on account of network effects, coupled with the exit of efficient competitors from the market, cannot be easily self-corrected by market forces. This should be a matter of conceren for competition authorities.

This is, however, not to suggest that any form of discounted pricing by an online business should always be frowned upon or be treated as being predatory. As in all other sectors, Internet-based businesses may also use various types of introductory or promotional prices, without such conduct necessarily falling foul of the principles of competition law. The questions that we need to ask are - what is the conduct in question; for how long is it carried out; and what will be its ultimate impact on competition in the sector? Different jurisdictions have adopted varying tests to assess what would amount to predatory or unfair pricing under their competition law framework. This is discussed in a later section of this paper.

\subsection{Approaches to competition enforcement}

What should the appropriate role for competition authorities be, in ensuring that Internet-based businesses function within a competitive framework? There are broadly two positions on this question.

The first view relies on the Schumpeterian idea of creative destruction. It argues that dominance in a new economy market is likely to be temporary, on account of rapid technological change, and the "constant fear of being outdone by a new product" (Monti, 2004). Supporters of this view argue that antitrust intervention is likely to be rendered both unnecessary and undesirable, except in the most unusual of circumstances, on account of the following factors:

1. There is a high likelihood of periodic paradigm shifts that will upset the 
existing order. Therefore, innovation will ensure that the market corrects itself without any need for specialised enforcement action (Teece and Coleman, 2003);

2. The pace of decision making by competition authorities and the technical expertise available with them is not adequate to assess the competition issues in these innovative and fast-moving sectors. There is a mismatch between law time - time taken by authorities in deciding a case - and new-economy real time, which can cause the ultimate findings to become irrelevant or ineffectual (Posner, 2000); and

3. Excessive intervention by competition authorities may leave firms with less incentives to innovate (Monti, 2004).

While there is merit in these arguments, we find that appropriate role of these factors is in aiding a suitable competition response to new economy businesses, rather than precluding intervention by competition authorities. For instance, the idea that Schumpeterian innovation will eliminate the effects of any dominance needs some reflection in light of Microsoft's anti-competitive tying of products along with its operating systems. These bundling practices continued for decades and before they were eventually brought to a halt after a series of investigations by competition authorities across the globe. Innovation alone was not able to fix the problem. Google is now going through a similar process of investigations in respect of its search, advertising and Android businesses. Yet interestingly, despite the large user base and innovation capacity of Google, it has not managed to make a dent in the Facebook's extensive social networking platform, which raises concerns about the extent to which Facebook has achieved market power.

These examples suggest that innovation, i.e. improvements in product features, may not suffice in competing with the dominance acquired by incumbents. The market may have to wait for a significant amount of time before the next disruptive innovation comes along and completely alters the underlying market structure. In that period, the resource allocation will be distorted with elevated prices, the extraction of consumer surplus, and large profits for incumbents. The resources and market power acquired by the dominant firm may enable it to capture new markets, creating a fresh cycle of innovation, scale and dominance.

The economics of competition policy is sector neutral; new economy businesses should be governed by the same competition assessment framework that applies to all other sectors, while reflecting the distinct characteristics of this segment. This would involve looking at features like economies of 
scale, network effects and the possibility of consumers being locked-into a particular network, while undertaking competition law enforcement against such businesses (Monti, 2004). In general, this approach involves the identification of the relevant market, establishing whether the firm in question is a dominant player in that market, and then an assessment of whether there has been an abuse of dominance. This is also the approach followed by the CCI while dealing with allegations of anti-competitive conduct by Internet-based businesses, as discussed subsequently in the paper.

Economides (2004) notes that the existence of strong network effects in some markets, can result in significant inequalities in market shares and profits, even in the absence of any specific anti-competitive conduct. Given this, any attempt by competition authorities to influence the market structure, for instance by trying to induce more competition, could prove to be counterproductive and may in fact diminish the overall social surplus. It is therefore important to draw a distinction between the inherent nature of competition in a network industry, on account of the structural features of the market in question, and a situation where a firm has adopted exclusionary practices to force the market to tip in its favour.

Interventions by competition authorities to correct these problems need to be rapid. In the words of the Supreme Court of India, "In the event of delay, the very purpose and object of the Act is likely to be frustrated and the possibility of great damage to the open market and resultantly, country's economy cannot be ruled out". ${ }^{27}$ As noted earlier, the pace of growth of Internetbusinesses is much faster than other traditional sectors. The opportunity for making a difference lies in the window of time before network effects have set in. This calls for the adoption of robust and time-bound systems by competition enforcement agencies to ensure that their findings remain relevant in light of the changing market conditions. One way in which this system can be improved is by allowing competition authorities the power to accept commitments from the firms whose conduct gives rise to potential competition concerns, without the need for a full fledged investigation.

The European Commission (EC)'s practice of accepting 'commitment decisions', which are binding on the party making them, without establishing an infringement, is a good example. ${ }^{28}$ The procedure for commitment decisions is generally shorter than the time taken for a detailed investigation and find-

\footnotetext{
${ }^{27}$ Competition Commission of India v. Steel Authority of India Limited, (2010) 10 SCC 744 .

${ }^{28}$ Article 9 of Regulation (EC) No 1/2003 on the implementation of Articles 101 and 102 of the Treaty on the Functioning of the European Union (TFEU).
} 
ing of infringement. This allows the EC to address identified competition concerns in a swift and effective manner, hence making it possible to quickly restore undistorted conditions of competition in the markets (EC, 2013). As noted by Joaqun Almunia in the context of Google's anti-trust investigation, "fast-moving markets would particularly benefit from a quick resolution of the competition issues identified. Restoring competition swiftly to the benefit of users at an early stage is always preferable to lengthy proceedings, although these sometimes become indispensable to competition enforcement" (Almunia, 2012). Similarly, the FTC rules also allow a party that is being investigated by the Commission to settle the charges made against it by signing a consent agreement, without admitting its liability. If the FTC accepts such a proposed consent agreement, it places the order on the record for thirty days of public comment, before taking a final decision on it. ${ }^{29}$

The law in India does not confer explicit powers on the CCI to enter into such settlements. The Madras High Court has, however, made some observations in this regard. In the context of a settlement entered into between the parties pending an investigation before the CCI, the Court held that it is possible within the scheme of the Act to allow settlements and compromises to be reached between parties. This is subject to the Commission finding that such settlements would not (i) lead to the continuance of anti-competitive practices; (ii) allow the abuse of dominant position to continue; and (iii) be prejudicial to the interests of consumers or to the freedom of trade. ${ }^{30}$

This case was decided in the context of the CCI's power to accept a settlement between the parties (the informant and the opposite party), and not one where an entity being investigated by the CCI directly offeres a commitment to the Commission. While the CCI could very well read this authority into the wide powers conferred upon it under the Act, it would be useful for the Parliament to clarify this issue by laying down appropriate provisions for CCI's settlement powers in the Act.

\footnotetext{
${ }^{29}$ See FTC (2008).

${ }^{30}$ Tamil Nadu Film Exhibitors Association v. Competition Commission of India, High Court of Madras, Writ Appeal Nos. 1806 and 1807 of 2013, decided on March 27, 2015.
} 
Working paper No. 194

\section{Competition concerns relating to conduct of investors}

There is a need to look beyond firms and cartels of firms to the behaviour of cartels of investors, in thinking about the race to use financial capital as a competitive weapon in order to capture network effects.

The valuation and prospects of an investment are likely to be affected, by the very fact of a formal investigation being instituted, and certainly so if a final finding of anti-competitive conduct is made against it. There is also the possibility of the competition authority imposing a direct penalty on the investor if it is found to be responsible for, or has contributed to, any contravention by the portfolio company. In addition, there could be situations where the conduct of the investor itself gives rise to competition concerns by creating distortions in the underlying markets in which its portfolio companies operate.

\subsection{Common ownership of competing firms}

Horizontal shareholdings, where a common set of investors own significant shares in competing firms in concentrated markets, have the potential to reduce the incentives of the firms to compete with one another (Elhauge, 2016). This is attributed to the fact that in such situations the owners (i.e. investors) would not benefit from one firm increasing its sales through price cuts as that would be at the cost of the sales of a competing firm that is also owned by the same investors. The incentive therefore would be to keep market-wide prices high rather than trying to capture the market share of other co-owned firms.

Taking the example of the airlines industry in the United States, Azar et al. (2015) show that common ownership of firms by diversified institutional investors had a large and significant positive effect on product prices. They concluded that "product prices are 3-11\% higher because of common ownership, compared to a counter-factual world in which firms are separately owned, or in which firms entirely ignore their owners' anti-competitive incentives."

The PE industry has examples of competitors being funded by common investors, giving rise to competition concerns at a global level as well as in domestic markets. For instance, the leading technology fund Tiger Global Management LLC (Tiger Global) has invested worldwide in a number of 
taxi aggregation companies such as in Ola in India, Didi Chuxing (formerly Didi Kuaidi) in China and GrabTaxi in Singapore. In December, 2015 Tiger Global also acquired a stake in Uber Technologies, the key competitor of each of these taxi aggregation businesses, giving rise to concerns about the potential conflict of interest (Mac and Solomon, 2015). Interestingly, Didi Chuxing itself had invested in several of Uber's competitors globally, including Ola in India. The announcement of Uber's China business merging with Didi that came out in in August, 2016, therefore, led to the creation of strong direct and indirect shareholding linkages between all these companies. This interlocking structure of shareholding is likely to influence the future of competition in this industry in India. ${ }^{31}$

In the Indian scenario, Tiger Global has invested in both Flipkart and Shopclues, businesses which compete directly with each other in the e-commerce marketplace business. It is also a large stakeholder in the online fashion retail segment, with five of the most-funded startups in this segment being in Tiger Global's portfolio. ${ }^{32}$ Similarly, Nexus Venture Partners, another major investor in Internet businesses, holds a stake in competing firms Snapdeal and Shopclues. Other examples include the investment by Norwest Venture Partners in Quikr and Sulekha (online classifieds) and Sequoia's investments in Zaakpay and Citrus (online payment gateways); Grofers and Peppertap (online grocery delivery); TinyOwl and Zomato (online food delivery) and Practo and $1 \mathrm{mg}$ (online doctor search). ${ }^{33}$ Given the dynamic nature of online businesses, some of these may be cases where one portfolio company changed its business model after the investment was made, hence bringing it in direct conflict with another investment or removing such conflict.

A related issue concerns established global players making strategic investments in startup ventures that are engaged in the same line of business. eBay's investment in Snapdeal, with both firms operating in the e-commerce marketplace in India, is a case in hand. ${ }^{34}$ China's Alibaba group presents another such example. It has invested in One97 Communications, the com-

\footnotetext{
${ }^{31}$ In July, 2015 Didi Chuxing had entered into a global alliance with Ola, GrabTaxi and Lyft in United States to allow international travelers to use their home applications to hail taxis in each others regions. The fate of this alliance is now uncertain in light of the Uber China-Didi Chuxing merger. See Punit (2015) for details of the global alliance and Kalanick (2016) for the merger announcement.

${ }^{32}$ See Punit (2016).

${ }^{33}$ See Dalal and Verma (2015b).

${ }^{34}$ As per Dalal and Verma (2015a), the agreement entered into between eBay and Snapdeal allows the former to increase its future stake in Snapdeal and also limits SoftBank, currently the largest investor in Snapdeal, from increasing its stake beyond 49 percent.
} 
pany that owns the Paytm brand, and Snapdeal, entities that compete with each other in the e-commerce space in India.

Minority shareholding in a competing firm or interlocking directorates could become another potential area of concern. ${ }^{35}$ Such arrangements "can have negative effects on competition, either by reducing the shareholder's incentives to compete or by facilitating collusion" (OECD, 2008). To address these concerns, investors often choose to adopt internal systems that help in avoiding direct conflicts of interest, for instance, by not placing the same person on the board of directors of competing firms. However, it is inevitable that certain business information would flow from the nominee directors to the investor or through the contractually agreed information rights that are a common part of PE transactions. In addition to this, investors also typically negotiate a veto list or a negative list of items on which the portfolio company cannot take action without the investor's concurrence. Taken together, these rights can grant an investor control over the strategic decisions of its portfolio companies. This becomes particularly problematic where the strategic decision making is influenced by the investor's knowledge of its own business plans or that of competing firms in which it has invested.

\subsection{Investor-facilitated buyouts}

The Internet economy witnesses frequent entry and exit of market players, with businesses using mergers and acquisitions as a strategy to consolidate their market share, eliminate potential threats or expand into new lines of business. Prominent examples include Flipkart's acquisition of Myntra, Ola's acquisition of rival taxi-aggregator TaxiForSure, ${ }^{36}$ ibibo's acquisition of redBus, Snapdeal's acquisition of Freecharge and Flipkart-backed Myntra's acquisition of competing fashion e-tailer Jabong.

Interestingly, the buyouts of smaller firms by larger competitors, operating in the same or similar line of business, often take place under circumstances where both the players are tied together by common investors. This was seen in case of Flipkart's acquisition of rival fashion e-tailer Myntra in May, 2014

\footnotetext{
35 "Interlocks" can be direct, where the same person sits on the boards of two related companies or indirect, if the two companies are linked through different people who are related through a common source, or sit together on the board of an unrelated company.

${ }^{36}$ ANI Technologies Pvt. Ltd., which owns the Ola brand acquired Serendipity Infolabs Pvt. Ltd., the owner of TaxiForSure in March, 2015 in a US\$ 200 million cash and equity arrangement. See Mishra (2015) for a detailed description of the background to the transaction.
} 
in a deal that was estimated to be valued at US\$300 million, making it the biggest acquisition in the Indian e-commerce sector till date. ${ }^{37}$ At the time of the transaction, two of Myntra's biggest investors, Accel India Venture Fund (Accel) and Tiger Global were also co-investors in Flipkart, and were reportedly responsible for propelling the deal. ${ }^{38}$ Prior to this, Flipkart had also acquired Letsbuy, an online retailer focusing on electronics, where again Accel and Tiger Global were the common investors.

Investors may often promote the consolidation of their portfolio businesses with the goal of seeking a higher valuation for the merged entity or to compete more effectively with a bigger player (and hence increase profitability). Strategic thinking between investors and firms may be shaped by the need to cut the losses arising from a portfolio company's business, as reported in case of the Uber-Didi merger in China. Both Uber and Didi were reportedly incurring heavy losses in China in an attempt to keep "rides cheap and drivers well-paid". ${ }^{39}$ Uber and Didi share four common investors: asset manager BlackRock, Chinese investment manager Hillhouse Capital Group, hedge fund Tiger Global and insurer China Life (Reuters, 2016b).

In India, M\&A deals involving online firms that satisfy the thresholds laid down in the Act would come under the scanner of the CCI to determine if the combination may cause an appreciable adverse effect on competition in the relevant market. When the yardsticks of the old economy are applied, the magnitudes are small and would not attract scrutiny by the CCI. ${ }^{40}$ Such transactions could, however, still come under the competition authority's lens if it can be shown that the two or more investors have entered into an anticompetitive agreement to determine prices or limit the supply of services in violation of Section 3 of the Act. This issue is discussed later in some more detail.

Where a smaller competing business is acquired by a dominant player leading

\footnotetext{
${ }^{37}$ See Kurup (2014).

${ }^{38}$ Kurian and Sharma (2014) report that at the time of the acquisition, Tiger and Accel together held 53 percent shares in Myntra and around 40 percent in Flipkart.

${ }^{39}$ Huang (2016) reports that Uber has lost approximately US $\$ 2$ billion in its Chinese operations to match Didi's practices of "buying up market share". The merger may also have been precipitated by the China government's new regulations legalizing ridehailing services and forbidding these companies from setting fares below cost to push out competitors.

${ }^{40} \mathrm{~A}$ similar argument is being taken up by Didi Chuxing in China on the grounds that the financial metrics of the transaction do not meet the filing requirements as Uber China and Didi are not yet profitable yet and Uber's turnover in China did not meet the trigger requirement for the anti-trust process (Reuters, 2016a).
} 
to a substantial elimination of competition, the CCI could also follow the lead of the European Court of Justice (ECJ) in reviewing such agreements under Section 4 of the Act, which deals with abuse of dominant position. In the Continental Can case, the ECJ noted that Article 86 of the EC Treaty (now Article 102 of the TFEU, which is similar to Section 4 of the Act) could be used to prevent a dominant undertaking from abusing its dominant position by acquiring a competitor. If the position held by the undertaking is so dominant that the acquisition would seriously endanger consumers' freedom of action in the market, then the acquisition could in itself amount to an abuse of dominance, irrespective of any fault of the dominant undertaking. ${ }^{41}$

\section{Present law and CCI's jurisprudence}

The CCI has the mandate to look into both unilateral anti-competitive conduct, i.e. abuse of dominant position, and concerted action in the form of agreements or combinations (merger, amalgamation or acquisition of control) that cause an appreciable adverse effect on competition in India. ${ }^{42}$ Our focus here is mainly on the first category of cases. While CCI's jurisprudence on this subject is still evolving, there have been a few instances where practices of Internet-based businesses have been questioned before the Commission on grounds such as predatory pricing, exclusivity conditions and discriminatory tactics. So far, these cases relate to online e-commerce marketplaces, online taxi aggregation services and online search advertising.

In most situations the Commission did not find sufficient merits to refer the matter for detailed investigation under the Act, Ola's services in Bengaluru, a series of cases against Google and now the Uber case referred by COMPAT, being the only notable exceptions. Having said that, we find that an analysis of the cases that have come up so far is still useful for gaining an insight into the Commission's thinking about the application of competition law to network industries generally and Internet-based businesses in particular.

\footnotetext{
${ }^{41}$ Europemballage Corp and Continental Can Co Inc. v. Commission, ([1973] ECR $215)$.

${ }^{42}$ Sections $19(3)$ and $20(4)$ of the Act lay down the factors to be considered by the CCI while assessing whether an agreement or combination leads to an appreciable adverse effect on competition. These include factors such as, creation of entry barriers, hindering entry or driving out existing competitors, benefits accrued to consumers, improvements in production or distribution processes and promotion of technical scientific and economic development.
} 


\subsection{Relevant market analysis}

CCI's assessment of any suspected abuse of dominance begins with a determination of the 'relevant market' in which the dominance is to be tested. The concept of relevant market under the Act includes the relevant product market - all products or services that are regarded as being substitutable by consumers, by reason of characteristics, prices and intended use, and the relevant geographic market - an area in which the conditions of competition are distinctly homogeneous. The first question therefore is to determine whether online and offline markets should be regarded as part of the same relevant market? We find that the CCI's response to this issue has varied depending upon the sector in question and the particular circumstances of the case.

\subsubsection{Relevant product market}

In the context of the online e-commerce businesses, the Commission observed that buyers tend to weigh the options available to them in offline and online markets before making a final decision, taking into account the differences in discounts and shopping experience. A significant increase in price in one segment will cause the buyer to shift to the other segment. Therefore, "these two markets are different channels of distribution of the same product and are not two different relevant markets". ${ }^{43}$

In another case, the informant argued that if a given book is exclusively distributed through an e-commerce firm, it is not substitutable by another book distributed by brick and mortar stores, hence making it a separate relevant market. The Commission disagreed, holding that individual products cannot be construed as a relevant market by themselves. It was of the view that none of the e-commerce platforms were individually dominant in either the overall distribution market or for the online segment, and therefore an assessment of the alleged abuse of dominance by such e-commerce firms was not required. ${ }^{44}$ In a similar vien, the CCI's prima facie view in a case filed by the

\footnotetext{
${ }^{43}$ Ashish Ahuja v. Snapdeal and others, (Case No 17 of 2014).

${ }^{44}$ Mohit Manglani v. Flipkart India Private Limited and others, (Case No 80/2014). The Commission decided not to delineate the relevant market or express an view on whether an e-commerce platform would constitute a separate product market or a sub-segment of the larger market for distribution of a product. In this context it would be relevant to refer to the decision of the Competition Appellate Tribunal in North East Petroleum Dealers Association v. CCI, Appeal No. 51 of 2014 where the Tribunal held that the CCI should not confuse the prima facie assessment of the case with the final determination of the case. For instance, it should not make observations about whether or not a player was
} 
Real Estate Brokers' Association of India against online platforms like Magicbricks, 99acres, Housing.com and others was that these online platforms and the off-line traditional brokers are offering similar services to customers and hence form part of the same relevant market. ${ }^{45}$

In contrast, the CCI has, in its prima facie assessment of the several cases filed against Google alleging abusive practices in respect of its online search and search advertising businesses, delineated "the market for online search advertising in India as the relevant market" and prima facie found Google to be in a dominant position in that relevant market. ${ }^{46}$ In doing so, the Commission has distinguished the online search market from the markets relating to other offline forms of advertising.

In case of taxi aggregation services, the CCI has held 'radio cabs service' to be a relevant market by itself, on the ground that consumers do not find such services to be substitutable with other modes of transport. It cited "convenience in terms of time saving, point-to-point pick and drop, pre-booking facility, ease of availability even at obscure places, round the clock availability, predictability in terms of expected waiting/ journey time etc." as relevant characteristics of radio taxis, which are not available in other modes of road transport. ${ }^{47}$ However, in another case filed by Indian taxi company, Meru cabs, against Uber's alleging anti-competitive practices in the city of Kolkata, the CCI adopted a slightly different test. It looked at the active presence of metered yellow taxis in the city and concluded that in this case radio taxis and yellow cabs form part of the same relevant market. ${ }^{48}$ In another case filed against Ola the informants had tried to defined a market for "paratransit services' in NCR, comprising of auto-rickshaws, black-yellow taxis and city taxis. This was rejected by the CCI on the grounds that there are certain differences in the comfort, time taken and consumer perception between these modes of transport and therefore 'radio taxi services' constitute a separate

in a dominant position or the general tenability of the allegations.

${ }^{45}$ Confederation of Real Estate Brokers' Association of India v. Magicbricks.com and others, Case No. 23 of 2016, order dated.

${ }^{46}$ See Albion InfoTel Limited v. Google Inc and others, Case No. 46 of 2014, order dated 12 September, 2014.

${ }^{47}$ Fast Track Call Cab Private Limited v. ANI Technologies Pvt. Ltd., Case No. 6 of 2015. The CCI repeated this reasoning in its prima facie orders in Mega Cabs Pvt. Ltd. v. ANI Technologies Pvt. Ltd., Case No. 82 of 2015 and Meru Travel Solutions Private Limited v. Uber India Systems Pvt. Ltd., Case No. 96 of 2015.

${ }^{48}$ Meru Travel Solutions Private Limited v. Uber India Systems Pvt. Ltd, Case No. 81 of 2015. Ease of booking of yellow cabs, predictability in terms of availability and low pricing were among the factors considered by the CCI while making this assessment. 
market. ${ }^{49}$

In the Kolkata case, the Commission went on to observe that even if the informant's definition of relevant market were to be accepted, Uber could not be held as being in a dominant position in Kolkata as there appeared to be stiff competition between Uber and Ola and Ola held a comparatively larger market share. The Commission has also made a similar observation in other cases. This raises interesting issues about whether it is possible for more than one firm to be dominant in one market, a question that is particularly relevant in the context of network industries that are expected to be dominated by a few big players. We highlight this as one of the questions for further research.

\subsubsection{Relevant geographic market}

As discussed above, the relevant market definition for Internet-based businesses often involves an assessment of whether brick-and-mortar substitutes are available for the given product or service (Kagan, 2011). That logic also extends to the examination of the relevant geographic market, to account for the presence of other competing businesses. As noted by the United States District Court, Virginia, the Internet is a giant network which interconnects innumerable smaller networks - it is not a place or location that can be defined with outer boundaries. The Court therefore found that the geographic market could not be restricted to the users of a particular service, in this case subscribers of America Online (AOL), "not only because there are other persons with access to the Internet, but also because there are other means of advertising to those persons and to AOL subscribers." 50

Defining the geographical market acquires an interesting dimension in cases where Internet platforms use the customer's or merchant's location as a useful matching tool. This sort of geographical segmentation helps in the efficient distribution of online goods and services, while also allowing for customisation (SIAA, 2014). The conditions of demand and supply of online cab hailing services, will for instance, differ drastically from one area to another. The CCI applied this logic in the taxi aggregation cases, to hold that the relevant geographic market was limited to the specific city in question. Firstly, on the ground that the operations of radio cabs are restricted to city limits. Secondly, because the regulatory architecture governing them also varies

\footnotetext{
${ }^{49}$ Vilakshan Kumar Yadav and others v. ANI Technologies Private Limited, Case No. 21 of 2016, CCI order dated 31 August, 2016.

${ }^{50}$ America Online, Inc. v. GreatDeals.net, 49 F. Supp 2d 851, 858 (E.D. Va. 1999).
} 
from one state to another.

We conclude with two observations. One, competition authorities often lean towards a qualitative analysis for determining the interchangeability between products, without necessarily relying on consumer usage data or other quantitative factors. Accordingly, the more unique the 'characteristics' of a service or the more niche its 'intended use', the higher the possibility of it being regarded as not having any close substitutes. Two, the use of geo-location tools to ascertain the location of potential users and target services to them could also lead to such businesses being delineated as independent relevant markets on the basis that the competitive constraints faced by such businesses are location-specific. This means that small firms providing innovative or unique services, which may often be linked to the consumer's geographic location, could well be designated as a separate relevant market, thus increasing the possibility of them being found to be dominant within that ecosystem.

\subsection{Determination of dominance}

The Act defines 'dominant position' as a position of strength in the relevant market that allows a firm to: (i) operate independently of prevailing competitive forces; or (ii) affect its competitors, consumers or the relevant market in its favour. It is quite clear from the wording of the section and the decisions of the CCI, that what the Act prohibits is the abuse of a dominant position that has already been acquired by an enterprise or a group. This flows from the recommendation of the Raghavan Committee (2000), which formed the basis for the enactment of the present law. ${ }^{51}$ The Committee was of the view that "The law should ensure that only when dominance is clearly established, can abuse of dominance be alleged. Any ambiguity on this count could endanger large efficient firms".

This position is influenced partially by the attempt to correct the inadequacy of the Monopolies and Restrictive Trade Practices Act (MRTP Act) - the predecessor law to the Act - which historically prohibited the acquisition of monopoly power per-se, negatively affecting the ability of Indian firms to grow beyond statutorily pre-determined market thresholds. Consequently, the legislative process of drafting the Act ensured that the acquisition of monopoly power is not frowned upon but only its abuse is. Similarly, Article

\footnotetext{
${ }^{51}$ The Raghavan Committee was constituted by the Indian government to recommend a suitable legislative framework on competition law. See Chakravarthy (2006) for a detailed discussion on the Raghavan Committee report and the process of drafting the Act.
} 
102 of the TFEU (on which Section 4 of the Act is substantially based) also makes it a prerequisite for competition agency to first establish the dominance of the firm. ${ }^{52}$

In contrast, Section 2 of the Sherman Act in the United States, recognises monopolisation, attempt to monopolise and conspiracy to monopolise as punishable offences. Monopolisation, as defined there, means the possession of monopoly power in the relevant market and the willful acquisition or maintenance of that power, as distinguished from growth or development as a consequence of a superior product, business acumen, or historic accident. ${ }^{53}$ Establishing an attempt to monopolise, on the other hand, requires proof "(1) that the defendant engaged in predatory or anticompetitive conduct with (2) a specific intent to monopolize and (3) a dangerous probability of achieving monopoly power." 54 Therefore, it is possible for a firm that uses predatory strategies to tip a networked market in its favour to be found to be acting in violation of the provisions of Section 2 of the Sherman Act, even if it is not holding monopoly power at the time of employing the predatory tactics. Indian law, however, does not provide for such powers.

Next, we turn to examining the factors used for determining the dominance of a firm. As per the Act, these factors to include, market share, size and resources of the firm, size and importance of competitors, vertical integration of the service network, market structure and entry barriers. ${ }^{55}$ While it has been noted by the Commission that market share is not a decisive proof of dominance, it still tends to rely on it as the key factor in dominance cases, particularly at the prima facie stage. In the recent Meru order ${ }^{56}$ the COMPAT has specifically brought out the fact that dominant position under the Act means a 'position of strength' but it "does not say that this position of strength necessarily has to come out of market share in statistical terms". The Tribunal therefore urged the CCI to consider the question of dominance based on the overall picture of the radio taxi service market, including its funding status, global developments, network expansion strategies and asso-

\footnotetext{
${ }^{52}$ Article 102 however does not define the term 'dominance'. The ECJ has adopted the following definition in United Brands Company v. Commission, [1978] ECR 207, which defines it as "a position of economic strength enjoyed by an undertaking which enables it to prevent effective competition being maintained in the relevant market by giving it the power to behave to an appreciable extent independently of its competitors, customers and ultimately of consumers.".

${ }^{53}$ United States v. Grinnell Corp., 384 U.S. 563, 57071 (1966).

${ }^{54}$ Spectrum Sports, Inc. v. McQuillan, 506 U.S. 447, 456 (1993).

${ }^{55}$ Section $19(4)$ of the Act.

${ }^{56}$ Meru Travels Solutions Private Limited v. Competition Commission of India, Appeal No.31/2016, COMPAT order dated 7 December, 2016.
} 
ciated discounts.

Very often, market shares of specialised streams of Internet-based businesses are not readily available and any self-reported information released by the market participants may also not be reliable. ${ }^{57}$ Under such circumstances, market shares may need to be determined based on specially commissioned market reports, as seen in each of the taxi aggregation cases that have been brought before the CCI. The informants relied on reports prepared by research and analyst firms to assert the high market share, and hence dominance, of the opposite parties. ${ }^{58}$ In the case against Ola in Bangalore, the CCI relied on the informant's submission (based upon reliance on certain public news reports) that after its acquisition of competing business Taxi For Sure, Ola held 69 per cent market share in Bangalore. The Commission concluded that even though high market share was not the only factor to be considered, the fact that Ola had achieved a significantly high share in just 3 to 4 years of its operations did indicate a strong market position. It however rejected the other taxi aggregation cases, filed against Ola and Uber in respect of the markets in Delhi and Kolkata, on grounds of inauthenticity of the third-party analyst reports and unreliability of their information sources. The COMPAT has pointed out this lack of consistency in the Commission's approach towards the findings of these analysts reports. It noted that the very fact that the Commission found inconsistent results in the reports "could have been a good reason for the Commission to order an investigation to reach a decision on a matter which has attained significant interest in the Indian market place." 59

This discussion leads us to two observations. One, it is crucial that any market reports being used to assert dominance of an Internet-based business should follow a robust and consistent methodology of data collection, scrutiny and analysis. Two, there seems to be a reluctance on the part of CCI to call for the information from the respondents at the prima facie stage, even though doing so could have easily allowed the Commission to get a better approximation of their actual market shares.

\footnotetext{
${ }^{57}$ Dalal (2016) discusses the competing and exaggerated claims made by Ola and Uber regarding their market shares in India. In August, 2015, SoftBank Group, which is the largest investor in Ola asserted that it had 85 per cent market share in India. This was followed by a statement from Uber in March, 2016 that it held close to 50 per cent of the market share. Similarly, in the Chinese market, Didi Chuxing had claimed a market share of over 80 per cent, while Uber reported a share of 30 to 35 per cent (Huang, 2016).

${ }^{58}$ These studies computed the market shares of taxi aggregators based on parameters such as fleet size, active fleet size, and number of daily trips.

${ }^{59}$ Meru Travels Solutions Private Limited v. Competition Commission of India, Appeal No.31/2016, COMPAT order dated 7 December, 2016.
} 
The Act empowers the CCI with the statutory powers of a civil court, which includes summoning any person, production of documents and receiving evidence on affidavit. ${ }^{60}$ Further, the CCI (General) Regulations, 2009 specifically provide that the CCI can hold a 'preliminary conference', inviting the information provider and any other person, if necessary to form a prima facie opinion in a case. Given the limited number of players operating in the relevant market in the taxi aggregation cases, the CCI could have used these powers to verify the market shares of Ola and Uber in the relevant markets of Delhi and Kolkata. Absent this, there is a heavy burden on informants to procure market data on specialised streams of Internet-based businesses, accurate information on which is often not publicly available.

Moreover, while dismissing the cases against Uber in Delhi and Kolkata the CCI noted that there was insubstantial proof of individual dominance of either Ola or Uber in the respective demarcated city markets and that there exists robust price competition between the two firms. The Commission, however, did not dwell further on the possibility of 'double dominance' in these markets - can two individual firms, without any economic linkages, be considered to be individually dominant in the same relevant market at the same time? ${ }^{61}$

A similar issue came up in the Direct-to-home (DTH) services case, ${ }^{62}$ where the informant argued that each of the DTH operators was individually dominant in the relevant market and had abused its dominant position. This contention was rejected by the Commission, observing that "Every single player in any relevant market cannot be said to possess such dominance... Individually, none of the DTH operators has dominant position in terms of Explanation (a) to section 4." The Commission, however, observed in this case that "the concept of dominance does centre on the fact of considerable market power that can be exercised only by a single enterprise or a small set of market players" (emphasis added). It would be interesting to see how the CCI might look at this issue in the context of abusive practices in duopoly-like situations, when the market is left with only two effective competitors and new

\footnotetext{
${ }^{60}$ Section $36(2)$ of the Act.

${ }^{61}$ This is different from the standard of 'joint/collective dominance' that has been adopted in jurisdictions like the European Union, where a number of firms, in particular because of common economic links, are able to adopt a common policy on the market. Indian law currently does not recognise the possibility of joint dominance by unrelated firms. The Competition (Amendment) Bill 2012 had proposed to add the words 'jointly and singly' to the language of section 4 of the Act to facilitate the CCI to enforce the standard of 'collective dominance' under Indian law.

${ }^{62}$ Consumer Online Foundation v. Tata Sky Limited, Case No 02 of 2009.
} 
entrants are practically locked out due to the dynamics of network effects.

\subsection{Unfair and predatory prices}

Having established the dominance of an enterprise, the next step is to assess whether it has abused that position in the manner stipulated under Section 4 of the Act. ${ }^{63}$ For instance, where a dominant search engine uses its leadership in the online search business to strengthen its position in specific vertical markets, such as online video, hotel and map searches; or a dominant game console manufacturer restricts game producers from writing software for other competing companies, hence creating entry barriers for them.

Imposing unfair or discriminatory prices in the purchase or sale of goods or services, including predatory pricing, is a form of abuse that is prohibited by the Act. Predatory pricing is defined to mean the provision of goods or services, at prices below cost, with a view to reduce or eliminate competition. As per the CCI's (Determination of Cost of Production) Regulations, 2009, the Commission will generally look at the 'average variable cost' as a proxy for marginal cost to assess whether a firm is selling below cost. ${ }^{64}$

As noted earlier, the cost structure of network industries is different from other traditional businesses, allowing players to adopt innovative pricing strategies. Relatively higher fixed costs and low variable costs, make it possible for many Internet-based businesses to adopt a low cost pricing strategy without necessarily being predatory. The Commission will therefore need to take view on whether the average variable cost is an appropriate standard for examining the pricing strategies of businesses with network effects and if not, what the appropriate standard should be.

In addition, the test of predation also requires that the strategy must be adopted with a view to reduce or eliminate competition. Therefore, the conduct should be such that it could lead to the exclusion of other players. In this context it would be relevant to note the following observation mace by the ECJ in the Tetra Pak case: "it must be possible to penalize predatory pricing whenever there is a risk that competitors will be eliminated... The aim

\footnotetext{
${ }^{63}$ Section 4 prohibits dominant enterprises from imposing unfair or discriminatory conditions or prices; limiting production; denial of market access, imposing unrelated supplementary conditions on contracting parties; or using dominance in one market to enter into or protect another market.

${ }^{64}$ The Regulations provide that in specific cases, depending on the nature of the industry, market and technology used, other relevant cost concepts such as 'avoidable cost', 'long run average incremental cost' or 'market value' may also be considered.
} 
pursued, which is to maintain undistorted competition, rules out waiting until such a strategy leads to the actual elimination of competitors". ${ }^{65}$

Courts in the United States have, however, adopted a slightly different standard for predatory pricing, which consists of the following two tests: firstly, the predatory price should fall below some relevant measure of cost; and secondly, the predator must have a reasonable prospect or a dangerous probability of recouping its investment in below-cost prices. ${ }^{6}$ The idea being that it should be feasible, given the structure and conditions of the market, for the firm to increase and maintain its prices at a level where it can fully recover its losses. As per the US Supreme Court, in the absence of this feature, predatory pricing will produce lower aggregate prices and enhance consumer welfare. In contrast, the established position in the European Union is that recoupment of losses is not a precondition to making a finding of predatory pricing. ${ }^{67}$

We note that the recoupment standard can be a useful test for looking into predatory practices in networked industries. It helps in drawing a distinction between two types of situations in which a firm may offer discounted prices. In the first case, a firm may be offering a low introductory price, perhaps to counter the market share of incumbents in a networked market. In the second, it may choose to adopt a predatory strategy, where the firm will not be able to profitably sustain its current pricing models even if it succeeds in achieving the dominant position in the networked market (Rubinfeld, 1998). In order to constitute a competition violation, the firm should be found to be using it discounting strategy for "bidding for future monopoly profits" (Katz and Shapiro, 1994).

It would be interesting to see whether the CCI will choose to read in the requirement of recoupment of losses, which is not specifically mentioned in the Act, as a requirement for establishing predatory pricing in India. For instance, the dissenting order in the National Stock Exchange (NSE) case, ${ }^{6}$ where NSE's zero-pricing strategy was challenged on the ground of being unfair and predatory, expressed the view that in the facts of that case it was important to consider the element of recoupment. The dissenting members highlighted the key features of a network industry relevant in the context of

\footnotetext{
${ }^{65}$ Case C-333/94P Tetra Pak International SA v. Commission, [1996] ECR I-5951.

${ }^{66}$ Brooke Group Ltd v. Brown and Williamson Tobacco Corp., 509 U.S. 209 (1993).

${ }^{67}$ Tetra Pak International SA v. Commission, [1996] ECR I-5951 and Case C-202/07 France Telecom v. Commission, [2009] ECR I-2369.

${ }^{68}$ MCX Stock Exchange Ltd v. National Stock Exchange of India Ltd., Case No. 13 of 2009.
} 
stock exchanges - complementarity between users leads to network effects; pricing and costing dimensions do not follow the same path as traditional industries; increasing returns to scale in production; fast pace of market expansion; and structural inequalities in market share and profit. Taking into account these special characteristics of a network industry, the dissenting opinion concluded that the zero price set by NSE for transactions could not be regarded as being unfair or predatory.

The majority decision of the CCI, however, did not subscribe to these views. It held that NSE's decision to offer currency derivatives trading at no cost was unfair from the perspective of its competitor MCX Stock Exchange Limited (MCX) that had brought the claim before the CCI. This was based on the logic that unlike NSE, which had other business segments (equity and equity derivatives - futures and options) where it enjoyed a virtual monopoly, MCX was a smaller player focusing only in the currency derivatives segment. The Commission concluded that unfairness of pricing, as distinct from the concept of predatory pricing, cannot be determined on the basis of some formula or an accounting process. It accordingly held that:

"Had NSE and MCX-SX been on equal footing in terms of resources directly available, spectrum and scale of operation, nationwide presence, length of existence etc. perhaps perception of unfairness would not have been so blatant and impossible to ignore, but in this case, the sense of the two being equal or even almost equal does not exist. Therefore, this Commission concludes that the zero price policy of NSE in the relevant market is unfair".

This line of interpretation has a special significance for the abuse of dominance allegations against Internet-based businesses, or new economy firms in general, by their traditional counterparts. CCI's reliance on a subjective 'competitive fairness' standard for determining allegations of unfair pricing means that Internet-based businesses, which generally have lower operational costs and easier access to capital as compared to their brick and mortar counterparts, can easily be regarded as indulging in unfair pricing. This leaves the room open for future complaints to cast discounted pricing strategies of cash-rich new industry firms as being unfair, using a 'big versus a small' paradigm. If the CCI chooses to view such cases under the unfair pricing standard adopted in the NSE case, it could potentially lead to a finding of abuse of dominance without the need for rigorous economic analysis to satisfy the tests of predatory pricing; or regard to the special characteristics of the network industries in which these businesses operate. This would be 
dangerous for innovation, growth and competition in the new economy.

In the context of conglomerate mergers, the Raghavan Committee (2000) noted that it is often believed that "firms operating in many markets can devastate their rivals through their potentially infinite capital resources". The Committee clarified that the law cannot presume that possession of capital will always lead to harmful pricing practices. Access to greater capital resources should therefore not in itself be the basis for concluding that a firm's practices are 'unfair' vis-a-vis its competitors. The focus should instead be on assessing whether these cash-rich businesses are using their resources for abusive or anti-competitive purposes. For instance, the allegations made against Ola and Uber referred to the fact that these companies have access to large sums of investor capital, which is being used to unrealistically incentivise drivers and offer deep discounts to customers. We argue that the focus of competition scrutiny in such cases should be on assessing whether these pricing practices are in fact predatory, based on economic analysis, rather than forming a subjective view on their unfairness.

\subsection{Attributing liability to investors}

Section 27 of the Act sets out the types orders that may be passed by the CCI after completing its inquiry into an alleged anti-competitive conduct. While the orders generally relate to imposition of penalty on, or corrective action by, the enterprise or persons concerned with the conduct in question, the proviso to the section allows the CCI to extend this liability to other group companies. So, if a startup has indulged in abuse of dominance and the CCI finds that "other members of such a group are also responsible for, or have contributed to, such a contravention", it may pass orders against them. A 'group' here refers to two or more enterprises where one of them exercises twenty six percent or more voting rights in the other; has the ability to appoint more than fifty percent of its board members; or controls its management or affairs. ${ }^{69}$

Under European Union law, the concept of 'undertaking' in the TFEU allows the EC to hold a related company liable for the anti-competitive conduct of its affiliates if it was in a position to exercise 'decisive influence' over the affiliate. The entities would then be regarded as constituting a 'single economic unit' and hence form part of the same undertaking, during the period of infringement. The EC has observed that "affiliation to the group deprives

\footnotetext{
${ }^{69}$ Section 5, Explanation (b) of the Act.
} 
the subsidiary company of the ability to act according to an economic scheme of its own. The 'given conditions' of such a subsidiary's operations are prescribed not by the market but by the instructions of the principal company". ${ }^{70}$

Such a presumption of decisive influence follows in cases where one company holds hundred percent of the shareholding in another. ${ }^{71}$ However, the EC has also adopted this logic to hold 50:50 joint venture partners ${ }^{72}$ and private equity investors ${ }^{73}$ liable for the conduct of their portfolio companies. In the Power Cables case, the EC found 26 entities, including the Goldman Sachs group, liable for cartelisation conduct involving sharing of markets and consumers in the power cables business. Goldman Sachs was held to be jointly and severally liable for the role played by its portfolio company, Prysmian S.p.A, in the cartel. This was decided taking into account the evidence that Goldman Sachs had been involved in the management decisions of Prysmian through voting rights and board representation.

As noted above, most large PE investments are structured in a way that entitles the investor to appoint one or more nominees to the board of directors of the portfolio company. The right to appoint more than half the board or ownership of over twenty six percent shares will automatically qualify an investor as a group company. However, an investor that does not satisfy these requirements can also be regarded as a group company depending on the facts and circumstances of each case. For instance, the investor may be entitled to exercise veto rights over a list of key governance and business decisions that cannot be taken without its consent. It may also have contractually secured certain information rights to examine the records of the company and receive periodic reports about the financial and operational aspects of the business. The cumulative effect of these rights and protections would need to be assessed to determine whether it amounts to exercise of control over the portfolio company.

The bigger challenge, however, would arise in situations where a group of unrelated investors collectively exercise control over the management or affairs of a startup. In practice, many private equity firms operate through syndi-

\footnotetext{
${ }^{70}$ Mausegatt v. Haute autorit, Case C-13/60. The CCI has also acknowledged the concept of a "single economic unit" in the context of internal arrangements between group companies which were held as falling outside the purview of Section 3 of the Act relating to anti-competitive agreements - Exclusive Motors Pvt. Ltd. v. Automobili Lamborghini S.P.A, Case No. 52 of 2012 and Shamsher Kataria v. Honda siel and Ors, Case No. 03/2011.

${ }^{71}$ Case C-97/08 P, Akzo Nobel and Others v. Commission, [2009] ECR I-8237, para. 60.

${ }^{72}$ Chloroprene Rubber, Case COMP/38629.

${ }^{73}$ Power Cables, Case AT.39610, Summary of Commission decision of 2 April 2014.
} 
cates or club deals. The definition of 'group' under the Act does not explicitly envisage the possibility of attaching joint liability to unrelated entities, under Section 27 of the Act.

In the context of its merger control decisions, the CCI has liberally construed the concept of 'control' to include the ability of investors to veto/block or exercise affirmative rights over strategic commercial decisions, such as opening of new offices, and hiring and termination of key personnel, ${ }^{74}$ approval of business pans, annual budget and commencement or termination of new lines of business. ${ }^{75}$ Interestingly, while granting its approval to the EtihadJet transaction the Commission held that the effect of the joint agreements, including the envisaged governance structure, established that Etihad was going to acquire joint control over Jet. ${ }^{76}$ This was held to be the case even though Etihad was acquiring only a 24 per cent stake in and did not have any veto or quorum rights. ${ }^{77}$ The CCI can be expected to import such concepts of control under a Section 27 analysis while attributing liability to investors for any anti-competitive conduct of their portfolio companies. In addition to this, the Commission will have to determine that the investor was in some way responsible for, or contributed to, the violation of the Act by the portfolio company.

It would also be interesting to see if the CCI chooses to view such cases under Section 3 of the Act, which prohibits horizontal agreements that adversely affect competition. Can PE investors be questioned for having entered into anti-competitive agreements that limit the competition in the markets in which their portfolio companies operate? This question can arise both in situations where the investors hold shares in competing companies, hence facilitating active collusion between firms or reducing their incentives to compete; and where investor-facilitated buyouts end up reducing the number of players in the market.

Elhauge (2016) notes that the anticompetitive incentives created due to horizontal shareholding could often be "purely structural", that is, they may occur even without any communication between the investors and the management of the portfolio company or coordination between the competing portfolio companies. For instance, the management of a portfolio company

\footnotetext{
${ }^{74}$ Multi Screen Media Private Limited/SPE Mauritius Holdings/SPE Mauritius Investments Limited, Combination Registration No. C-2012/06/63.

${ }^{75}$ Century Tokyo Leasing Corporation/Tata Capital Financial Services Limited, Combination Registration No. C-2012/09/78.

${ }^{76}$ Etihad/Jet Combination Registration No. C-2013/05/122.

${ }^{77}$ See Shroff and Uberoi (2014) for a detained discussion on the manner in which the CCI has defined control in combination cases.
} 
would know the identity of its investors as well as the fact that the same investors have also funded other rivals. In such a situation, the management may be incentivised to keep in mind the interests of the common investor, from whom it expects to receive further rounds of funding, when determining its business strategy. However, while examining the implications of common share ownership from a competition law perspective, one would need to expressly show that the anti-competitive acts of the portfolio companies were a consequent result of the common ownership among the investors. Competition authorities will therefore need to look into evidence of common investors using their ownership position to facilitate an agreement among the portfolio companies - for example, an agreement not to compete on price - before it can be established that such arrangements amount to a violation of competition law (Karp, 2016).

We find it relevant here to discuss the concept of 'hub-and-spoke' conspiracies where a 'hub' - a firm at one level of the market structure - coordinates an anti-competitive arrangement between competitors at a different level of the market - the 'spokes'. These arrangements consist of both vertical agreements between the hub and each spoke and a horizontal agreement among the spokes, to adhere to the terms set out by the hub. ${ }^{78}$ For instance, in the Apple e-books case in the United States, the court found that Apple had orchestrated a horizontal conspiracy among five leading book publishers in the United States by entering into individual agreements with each of them which led to an increase in the prices paid by consumers for e-books. ${ }^{79}$

The hub-and-spoke analysis is generally applied in the context of distribution arrangements between players operating at different levels of the production chain. ${ }^{80}$ It would be interesting to see if competition authorities will extend a similar analysis to arrangements between investors and portfolio companies. If they do, the key issue would be to determine whether concerted action by portfolio companies that are controlled by one or more common investors

\footnotetext{
${ }^{78}$ United States v. Apple, Inc., 791 F.3d 290, 314 (2d Cir. 2015).

${ }^{79}$ The objective of the agreements was to build collective pressure to cause Amazon to switch to an agency model of sale. Unlike a wholesale model, which allowed Amazon to determine the sale prices on its Kindle store, in an agency relationship the publisher sets the price that consumers will pay for each e-book and pays the retailer a fixed percentage of each sale.

${ }^{80}$ The concept of 'hub-and-spoke' cartels has been accepted by CCI in Fx Enterprise Solutions India Pvt. Ltd v. Hyundai Motor India Limited, Case No. 36 of 2014. Hyundai was alleged to have perpetuated a hub and spoke arrangement where bilateral vertical agreements between Hyundai and its dealers and horizontal agreements between the dealers were being maintained through the role played by Hyundai. The CCI found a prima facie case of a hub-and-spoke price collusion.
} 
would be sufficient to apply the hub-and-spoke conspiracy, even if the Commission cannot find direct evidence of an agreement between the portfolio companies.

\section{The way forward}

\subsection{The economic perspective}

Competition law assessment of industries in the new economy should necessarily be grounded in a deep understanding of the economic features of the markets in question. The business models of many Internet-based businesses are driven by the existence of network effects, where the value to a user increases with the total number of users on the platform. Direct and indirect network effects ensure that the utility of a social network like Facebook increases with each subscriber; online aggregators like Uber build scale with an increase in complementary users on both sides of their platform; and most content providers win advertisers as more users visit their pages. Online businesses are therefore eager to gain the first-mover advantage and quickly build scale to a level where they can exclude other competitors, often through strategies of deep discounting or by using dominance in one business to expand to a related field.

We also know that markets with network effects tend to be in the nature of natural oligopolies and therefore the most efficient outcome may be for the market to be dominated by a few firms. For instance, it may be more efficient if sellers of used cars can reach out to all potential buyers through two large platforms that compete with one another rather than having to go through ten smaller players. Given that fact, it would be counter-productive to prevent the market from following its natural course. At the same time, there is a role for competition authorities to see to it that the winners and losers in online markets are determined by the market forces, taking into account the relative efficiencies of the players, and not their exclusionary practices. The challenge, therefore, is to assess whether the firms that emerge as the online market leaders do so by virtue of their efficiencies or by indulging in abusive or exploitative market practices that will harm users in the long run. 


\subsection{Approach towards competition enforcement}

We propose that the following changes need to be considered by the CCI, while applying the provisions of the Act in the context of online businesses, particularly those with substantial network effects:

1. The economics of online businesses:

When looking into cases involving abuse of dominance by Internetbased businesses, the CCI should take into account the unique characteristics of such businesses, which include, rapid technological changes, phenomena of increasing returns, benefits of behavioural data collected from users and most of all, network effects. The existence of network effects confers a massive first-mover advantage on the business that is able to build scale at an early stage, allowing it to continue expanding at an exponential pace till other efficient competitors might be forced to exit the market. Relatively easy availability of capital further compounds these effects. Dominance should therefore be tested taking into account all these factors, as the self reinforcing nature of network effects will ensure that person who gets out in front will inevitably be rewarded with the highest market share.

For example, different cities in India are currently seeing Uber and Ola competing aggressively to quickly gain scale and outbid the others, while suffering huge losses in the process. Both these companies are heavily funded by $\mathrm{PE}$ investors, which fuels their ability to indulge in providing steep incentives to drivers and deep discounts to customers. Through a process of sustained below-cost pricing, these companies could succeed in ousting all other competing businesses out of the market and then start raising their prices. This has already started happening to some extent.

In October 2016, both Ola and Uber reportedly raised their fares in top cities and reduced the amount they pay as incentives to drivers. ${ }^{81}$ Uber is now reported to have hiked its fares in Delhi NCR by 10 to 15 percent in January 2017. ${ }^{82}$ These changes could be a result of a gradual recoupment strategy in markets where both companies have established a significant presence or it could also be a risk management strategy in light of the cases pending before the CCI. In either case, it highlights the need for the CCI to give due regard to the economic

\footnotetext{
${ }^{81}$ See (Shrivastava and Chanchani, 2016).

${ }^{82}$ See Live Mint (2017).
} 
principles that drive these online businesses and the long term impact of their conduct. As rightly noted by the COMPAT in its Meru order, the Commission should focus not just on the market shares of these firms but the "overall picture", which includes the status of funding in the industry, the existence of discounts and incentives and the primary goal of network expansion.

At the same time we also recommend that the CCI must also take a closer look at the role played by PE investors in determining the level of competitiveness in the industries that they invest in. This would include an examination of the conduct of investors acting in syndicates or club deals to influence the decisions of portfolio companies controlled by them.

2. Assessing the possibility of recoupment:

Access to substantial funds by firms in networked industries should, however, not in itself be seen as a ground of unfairness. Taking such an approach could potentially chill the inflow of investments into one of the most dynamic sectors of the Indian economy. The recoupment test can therefore be a useful tool for distinguishing between discounting practices that enhance consumer welfare and those that will harm consumers in the long run, once the player begins to charge monopoly profits. Therefore, we recommend that in cases where an online firm's predatory practices are being assessed, the CCI should also look into the possibility of recoupment of the losses being incurred, even though the definition of 'predatory price' under the Act does not mandate it to do so.

In a networked industry, there is a high likelihood that continuous predatory practices will gradually lead to the exit of other competitors. At the same time, network externalities create high entry barriers making it unprofitable for new firms to enter the market. The resulting market structure could therefore allow the dominant player to recoup some or all the losses that were incurred in order to facilitate the tipping of the market in its favour. Moreover, it is relevant to look at the possibility of recoupment not just on the basis of the market under consideration but also the other markets that the operator may have expanded into by leveraging its position in the first market.

In summary, we suggest that the CCI's approach should be to first assess whether the online business holds a position of dominance, with due regard to the economic principles discussed above. Next, it should 
examine whether the firm is indulging in below cost pricing, the period for which the practices continue and the likelihood of recouping any losses incurred in the process. The idea is to determine whether it would be feasible, given the structure and conditions of the market, for the firm to increase and maintain its prices at a level where it can fully recover its losses from that market or from the other markets that it operates in.

\section{Interoperability as a tool}

In appropriate cases, the CCI could adopt the essential facilities doctrine to mandate interoperability between a dominant player that is found to be indulging in the abuse of its position and other operators in the market. Interoperability between technology companies will facilitate open access, which is particularly important where the service being offered acquires the nature of an infrastructural facility that cannot be easily duplicated. For instance, imposing interoperability requirements on a dominant payments network can help extend the network effects of digital payments to the economy as a whole, rather than being limited to a closed network. Imposition of any such requirements will, however, need to be balanced against factors such as, the payment of fair and reasonable access fees, complexity of institutional arrangements required to monitor such arrangements and assessment of the impact on future innovation.

\section{Voluntary commitments:}

It is often argued that the pace of change in new economy industries is so fast and the issues so technical that it becomes difficult for competition authorities to react in time to prevent significant harm to competition. This calls for the need for Indian competition law to consider adopting a system of voluntary settlement of cases. This will allow market players, that could potentially be found to be acting in violation of the Act, to alter their behaviour, without the need for a full fledged investigation by the Commission. As a result, the CCI will be better placed to stop the harm before it has occurred, or at least while it is still in progress, but before the market structure has irrevocably altered in favour of one player. The proposed settlement process would be similar to the EC's process of 'commitment decisions' and the system of 'consent agreement orders' followed by the FTC in the United States.

At the same time, for cases that do go through a detailed investigation, 
there is a need for the CCI to maintain a strict time-bound process for the completion of the investigation and issuance of final orders. This is necessary to ensure that its findings remain relevant despite the rapidly changing market conditions in the new economy.

Lastly, we question whether the Indian competition law needs to be revisited in some manner to suit the requirements of competition assessment in the new economy. As in all other sector, the Act suggests that while considering such cases, the CCI should follow a sequential process of determining the relevant market; assessing whether the firm is dominant in that market; and finally whether it abused its dominant position. Therefore, unlike Section 2 of the Sherman Act in the United States, which recognises an 'attempt to monopolise' as an anti-trust violation, the Act requires a conclusive finding of dominance before any further action can be taken.

Do we need CCI to be similarly empowered to look into situations where a firm that may not yet hold a dominant position uses the benefits of network effects to systematically adopt predatory strategies for setting itself on a path of dominance? On one hand, such an approach could allow the CCI to prevent the harm before it is done - by ensuring that natural leadership in a networked market is not acquired through long term discounting and other abusive practices. On the other, it could deter new entrants from participating in online businesses due to the fear of a MRTP Act type regime that frowned upon the per-se acquisition of market power. It may be too early in the day to decide which of these concerns outweighs the other. However, this is an important question that needs to be revisited depending on the type of anti-competitive practices that we continue to see in the Indian online sector and the manner in which the CCI evolves its jurisprudence to address them.

\section{Conclusion}

In India, technology companies are generally revered as the source of technological progress. However, the problems of competition policy are universal and cut across all industries. The basic principles do not change. The purpose of competition policy is to stave off situations where a narrow set of firms have market power, and new players are not able to enter. Society gains when firms obtain profits and valuation through innovation, not through the crafty use of financial capital to kick off network effects. 
Online markets in India have many examples where players with access to significant capital resources are resorting to deep discounting tactics in order derive the long-term benefits of scale and network effects. Vast amounts of capital, which could otherwise be utilised for innovation and development, is therefore being systematically burned in order to achieve these benefits. In many cases, these practices are not necessarily limited to firms that are in the early stages of their business but have become an integral part of their business model, prompting a race to the bottom.

It is therefore an interesting time for the CCI to be looking into the different types of business practices being undertaken by online firms. We highlight that the CCI's approach in dealing with these cases involving new economy businesses must necessarily be informed by the specific economic characteristics that define these sectors. 


\section{References}

Almunia J (2012). "Statement of VP Almunia on the Google antitrust investigation." URL http://europa.eu/rapid/press-release_SPEECH-12-372_ en.htm.

Arakali H (2016). "Ola's ready to race ahead of the curve." URL http://www . forbesindia.com/printcontent/43507.

Arora R (2016). "CCI to decide on cashbacks given by online payment platforms like Paytm and Mobikwik." URL http://economictimes.indiatimes.com/ articleshow/52301239.cms?utm_source=contentofinterest\&utm_medium= text\&utm_campaign=cppst.

Azar J, Schmalz MC, Tecu I (2015). "Anti-Competitive Effects of Common Ownership." Ross School of Business Working Paper No. 1235. URL http: //papers.ssrn.com/sol3/papers.cfm?abstract_id=2427345.

Bhagya P (2006). "Everything You Need to Know About Unicorns In India." URL http://techstory.in/unicorns-in-india/.

Bob Briscoe AO, Tilly B (2015). "Metcalfe's Law is Wrong." URL http:// spectrum.ieee.org/computing/networks/metcalfes-law-is-wrong.

Busvine D (2016). "Uber says Didi deal frees resources for key Indian market." URL http://www.reuters.com/article/us-uber-india-idUSKCN11D23J.

Chakravarthy DS (2006). "Why India Adopted a New Competition Law." URL http://www.cuts-ccier.org/pdf/Why_India_Adopted_a_new_ Competition_Law.pdf.

Dalal M (2016). "Who's lying about market share: Ola or Uber?" URL http://www.livemint.com/Companies/LRaNYUrBjTD6qAdc3yDolJ/ Whos-lying-about-its-market-share-0la-or-Uber.html.

Dalal M, Verma S (2015a). "Does eBay have a sweetheart deal with Snapdeal?" URL http://www.livemint.com/Companies/7sYyArLcfy2CLmluhKDUOL/ Does-eBay-have-a-sweetheart-deal-with-Snapdeal.html.

Dalal M, Verma S (2015b). "Sequoia Capital bets big on hyperlocal start-ups in India." URL http: //www. livemint. com/Companies/L6dVNPtc4PhbadvXeCDY5H/ Sequoia-Capital-bets-big-on-hyperlocal-startups-in-India.html.

EC (2013). "Antitrust: commitment decisions - frequently asked questions." URL http://europa.eu/rapid/press-release_MEMO-13-189_en.htm. 
Economides N (2004). "Concepts in the Context of Monopolistic Competition." In DW Jansen (ed.), "Creating Services and Products," Bush Series in the Economics of Public Policy, p. 96 to 121. Edward Elgar Publishing. URL http: //www.stern.nyu.edu/networks/Economides_Competition_Policy.pdf.

Economides N, Flyer F (1998). "Compatibility and Market Structure for Network Goods." Discussion paper, Stern School of Business, New York University, EC-98-02. URL bttp:/1www.stern.nyu.edulnetworks198-02.pdf.

Economides N, Lianos I (2010). "A Critical Appraisal of Remedies in the E.U. Microsoft Cases." NYU Law and Economics Research Paper No. 10-02. URL https://papers.ssrn.com/sol3/papers. cfm?abstract_id=1523908.

Elhauge E (2016). "Horizontal Shareholding." 109 Harvard Law Review 126\%. URL http://papers.ssrn.com/sol3/papers. cfm?abstract_id=2632024.

Evans DS, Schmalensee R (2002). "Some Economic Aspects of Antitrust Analysis in Dynamically Competitive Industries." In JL Adam B Jaffe, S Stern (eds.), "NBER Book Series Innovation Policy and the Economy (Volume 2)," chapter 1, p. 1 to 50. MIT Press. URL http://www.nber.org/papers/w8268.pdf.

Farrel J, Katz ML (1998). "The Effects of Antitrust and Intellectual Property Law on Compatibility and Innovation." Antitrust Bulletin, Fall-Winter.

FTC (2008). "A Brief Overview of the Federal Trade Commission's Investigative and Law Enforcement Authority." URL https://www.ftc.gov/about-ftc/ what-we-do/enforcement-authority.

FTC (2013). "Google Agrees to Change Its Business Practices to Resolve FTC Competition Concerns." URL https://www.ftc.gov/news-events/press-releases/2013/01/ google-agrees-change-its-business-practices-resolve-ftc.

Goetz J (2015). "Four Numbers That Explain Why Facebook Acquired WhatsApp." URL http://sequoiacapital.tumblr.com/post/77211282835/ four-numbers-that-explain-why-facebook-acquired.

Graham C (2004). "Introduction." In C Graham, F Smith (eds.), "Competition, Regulation and the New Economy," p. 1 to 12. Hart Publishing.

Greenhalgh C, Rogers M (2010). Innovation, Intellectual Property and Economic Growth. Princeton University Press.

Huang Z (2016). "Uber's defeat in China is bad news for Chinese drivers and riders." URL http://qz.com/746984/ ubers-defeat-in-china-is-bad-news-for-chinese-drivers-and-riders/. 
Kagan J (2011). "Bricks, Mortar, and Google:Defining the Relevant Antitrust Market for Internet-Based Companies." New York Law School Law Review, 55, 271 to 292. URL http://www. nylslawreview.com/wp-content/uploads/ sites/16/2013/11/55-1.Kagan_.pdf.

Kalanick T (2016). "Uber China Merges with Didi Chuxing." URL https:// newsroom.uber.com/uber-china-didi/.

Karp BS (2016). "Antitrust Executive Order and Common Ownership." URL https://corpgov.law.harvard.edu/2016/05/24/ antitrust-executive-order-and-common-ownership/.

Katz ML, Shapiro C (1994). "Systems Competition and Network Effects." Journal of Economic Perspectives, 8(2), 93 to 115. URL http://brousseau.info/pdf/ cours/Katz-Shapiro\%5B1994\%5D.pdf.

Khan LM (2017). "Amazons Antitrust Paradox." Yale Law Journal, 126, 710. URL http://www.yalelawjournal.org/pdf/e.710.Khan.805_ zuvfyyeh.pdf.

Kurian B, Sharma S (2014). "Let's merge, Flipkart tells Myntra." URL http://timesofindia.indiatimes.com/business/india-business/ Lets-merge-Flipkart-tells-Myntra/articleshow/29582969.cms.

Kurup D (2014). "Flipkart buys out Myntra for USD 300 m." URL http://www.thehindu.com/business/Industry/ flipkart-buys-out-myntra-for-300-m/article6037600.ece.

Levy A (2015). "WhatsApp Backer Sequoia Said to Reap \$3.5 Billion in Deal." URL https://www.bloomberg.com/news/articles/2014-02-20/ sequoia-s-whatsapp-stake-said-worth-about-3-5-billion.

Liebowitz S, Margolis SE (1994). "Network Externality: An Uncommon Tragedy." Journal of Economic Perspectives, 8(2). URL https://www.utdallas.edu/ liebowit/jep.html.

Live Mint (2017). "Uber hikes taxi fares up to $15 \%$ in Delhi-NCR." URL http://www.livemint.com/Industry/499STkjXzKITvVjqUiccKJ/ Uber-hikes-fares-up-to-50-in-DelhiNCR.html.

Mac R, Solomon B (2015). "As Tiger Global Plays Both Sides In Uber War, Other Investors Are 'Furious'." URL http://goo.gl/DlofZp.

Malik O (2015). "In Silicon Valley Now, It's Almost Always Winner Takes All." URL http://www.newyorker.com/tech/elements/ in-silicon-valley-now-its-almost-always-winner-takes-all. 
Mazumdar J (2016).
lenge as losses force reality check." face new chal-
indianexpress.com/article/business/business-others/
e-commerce-firms-face-new-challenge-as-losses-force-reality-check/.

Mishra AK (2015). "Behind TaxiForSure's sellout." URL http://www. livemint. com/Companies/t7TozTlZCAmvtSxog30Q7L/Behind-TaxiForSures-sellout. html.

Mishra D (2016). "Paytm registers a four times increase in losses, Rs 1549 cr for FY'16." URL http://economictimes.indiatimes.com/articleshow/ 55951679.cms?utm_source=contentof interest\&utm_medium=text\&utm_ campaign=cppst.

Monti G (2004). "Article 82 EC and New Economy Markets." In C Graham, F Smith (eds.), "Competition, Regulation and the New Economy," p. 17 to 53. Hart Publishing.

Newcomer E (2016). "Uber Loses at Least $\$ 1.2$ Billion in First Half of 2016." URL https://www.bloomberg.com/news/articles/2016-08-25/ uber-loses-at-least-1-2-billion-in-first-half-of-2016.

OECD (2004). "Glossary of Statistical Terms." URL https://stats.oecd.org/ glossary/detail . asp?ID=6267.

OECD (2008). "Antitrust Issues Involving Minority Shareholding and Interlocking Directorates." Technical report, Organisation for Economic Co-operation and Development. URL http://www.oecd.org/competition/mergers/41774055. pdf.

OFT (2002). "Innovation and Competition Policy." Technical report, Report prepared for the Office of Fair Trading by Charles River Associates. URL http://webarchive.nationalarchives.gov.uk/20140402142426/http: //www.oft.gov.uk/shared_oft/reports/comp_policy/oft377part1.pdf.

Ovide S (2016). "Google and Facebook Divide Up Your Eyeballs." URL https://www.bloomberg.com/gadfly/articles/2016-11-21/ google-and-facebook-divide-up-your-advertising-viewing.

Posner RA (2000). "Antitrust in the New Economy." Chicago Unbound. URL http://chicagounbound.uchicago.edu/cgi/viewcontent.cgi? article $=1057 \&$ context $=1$ law_and_economics.

Press Note 3 (2016 Series) (2016). "Guidelines on Foreign Direct Investment on ECommerce." URL http://dipp.nic.in/English/acts_rules/Press_Notes/ pn3_2016.pdf. 
Punit IS (2015). "The new global anti-Uber alliance: Ola, Lyft, Didi Kuaidi and GrabTaxi agree to ride together." URL http://goo.gl/YlXJOH.

Punit IS (2016). "Tiger Global is now the biggest investor in online fashion retail in India." URL http://qz.com/741924/ tiger-global-is-now-the-biggest-investor-in-online-fashion-retail-in-india/.

Raghavan Committee (2000). "Report of High Level Committee on Competition Policy and Law." Technical report, High Level Committee on Competition Policy and Law set up by the Government of India. URL http://www.ccr.org.in/uploads/2/1/9/6/21961628/report_of_ high_level_committee_on_competition_policy_and_law.pdf.

Reuters (2016a). "China regulator says Didi, Uber deal will need Mofcom approval." URL http://www.reuters.com/article/ us-uberchina-m-a-didi-idUSKCN10D0J8.

Reuters (2016b). "Rivals Uber and Didi now sharing big investors." URL http://economictimes.indiatimes.com/articleshow/52791020.cms? utm_source=contentof interest\&utm_medium=text\&utm_campaign=cppst.

Rubinfeld DL (1998). "Antitrust Enforcement in Dynamic Network Industries." The Antitrust Bulletin, Fall-Winter, 859 to 882. URL https://www.law. berkeley.edu/files/dlr_enforcement.pdf.

Shah A (2016a). "How to make digital payments work." URL http://www .mayin. org/ajayshah/MEDIA/2016/digital_payments.html.

Shah A (2016b). "India's start-ups are lazy businesses." URL http://www.business-standard.com/article/opinion/ ajay-shah-india-s-start-ups-are-lazy-businesses-116050100681_ 1.htmll.

Shapiro C, Varian HR (1999). Information Rules: A Strategic Guide to the Network Economy. Harvard Business School Press.

Shrivastava A, Chanchani M (2016). "Ola, Uber raise fares in top cities, reduce driver incentives." URL http://economictimes.indiatimes.com/ articleshow $/ 54906937$.cms?utm_source=contentofinterest\&utm_medium= text\&utm_campaign=cppst.

Shroff C, Uberoi NK (2014). "Battle for Regulatory Supremacy: Ambiguity in the Definition of "Control" between SEBI and CCI." CUTS Institute for Regulation and Competition, CIRC Working Paper No. 09. URL http://circ.in/pdf/Battle_for_Regulatory_Supremacy_Ambiguity_ in_the_Definition_between_SEBI_and_CCI.pdf. 
SIAA (2014). "Geolocation Tools and Geographical Market Segmentation." URL https://www.ftc.gov/system/files/documents/public_ comments/2014/04/00010-89273.pdf.

Teece D, Coleman M (2003). "The Meaning of Monopoly: Antitrust Analysis in High-Technology Industries." In D Teece (ed.), "Essays in Technology Management and Policy," p. 340 to 384. World Scientific Publishing Co.

Turck M (2016). "The Power of Data Network Effects." URL http://mattturck. com/2016/01/04/the-power-of-data-network-effects/.

Vats R (2016). "Losses of top 10 e-commerce companies in India soar, show VCCEdge data." URL http://www.vccircle.com/news/consumer/2016/05/16/ losses-top-10-e-commerce-companies-india-soar-show-vccedge-data.

VCC (2016). "PE and VC dealmaking in India falls with a thud but over 1,000 startups got funded in 2016." URL http://www.vccircle.com/news/finance/2016/12/20/ pe-vc-dealmaking-india-fall-thud-over-1000-startups-got-funded-2016.

Watal R (2016). "Committee on Digital Payments." Technical report, Ministry of Finance, Government of India. URL http://finmin.nic.in/reports/watal_ report271216.pdf. 


\section{MORE BY THE AUTHORS}

- Patnaik, I., Felman, J., and Shah, A., (2017).An Exchange Market Pressure Measure for Cross Country Analysis, WP No. 189 (February).

Ajay Shah is Professor, NIPFP Email: ajay.shah@nipfp.org.in.

Smriti Parsheera is Consultant, NIPFP

Email: smriti.parsheera@nipfp. org.in.

Avirup Bose is Asst. Professor, Jindal Global Law School

- Chakravartti, P., and Mundle S., (2017). An Automatic Leading Indicator Based Growth Forecast for 201617 and The Outlook Beyond,WP No. 193 (March).

- Datta P., Malhotra S., and Tyagi S., (2017). Judicial Reviews and Money Bills, WP No. 192 (March).

- Rao, M. G., (2017). Budget 2017-|8: Business as Usual, WP No. 191 (March).

National Institute of Public Finance and Policy,

18/2, Satsang Vihar Marg, Special Institutional Area (Near JNU),

New Delhi 110067

Tel. No. 26569303, 26569780, 26569784

Fax: 91-11-26852548

www.nipfp.org.in 